\title{
MiR-26b, Upregulated in Alzheimer's Disease, Activates Cell Cycle Entry, Tau-Phosphorylation, and Apoptosis in Postmitotic Neurons
}

\author{
Sabrina Absalon, ${ }^{\star}$ Dawn M. Kochanek, ${ }^{\star}$ Venkatesan Raghavan, and Anna M. Krichevsky \\ Center for Neurologic Diseases, Brigham and Women's Hospital and Harvard Medical School, Harvard Institutes of Medicine, Boston, Massachusetts 02115
}

MicroRNA (miRNA) functions in the pathogenesis of major neurodegenerative diseases such as Alzheimer's disease (AD) are only beginning to emerge. We have observed significantly elevated levels of a specific miRNA, miR-26b, in the defined pathological areas of human postmortem brains, starting from early stages of $\mathrm{AD}$ (Braak III). Ectopic overexpression of miR-26b in rat primary postmitotic neurons led to the DNA replication and aberrant cell cycle entry (CCE) and, in parallel, increased tau-phosphorylation, which culminated in the apoptotic cell death of neurons. Similar tau hyperphosphorylation and CCE are typical features of neurons in pre-AD brains. Sequence-specific inhibition of miR-26b in culture is neuroprotective against oxidative stress. Retinoblastoma protein (Rb1), a major tumor suppressor, appears as the key direct miR-26b target, which mediates the observed neuronal phenotypes. The downstream signaling involves upregulation of Rb1/E2F cell cycle and pro-apoptotic transcriptional targets, including cyclin $\mathrm{E} 1$, and corresponding downregulation of cell cycle inhibitor p27/Kip1. It further leads to nuclear export and activation of Cdk5, a major kinase implicated in tau phosphorylation, regulation of cell cycle, and death in postmitotic neurons. Therefore, upregulation of miR-26b in neurons causes pleiotropic phenotypes that are also observed in AD. Elevated levels of miR-26b may thus contribute to the AD neuronal pathology.

\section{Introduction}

There are 5.3 million Americans living with Alzheimer's disease (AD), the major neurodegenerative disease of aging, and the number of people affected by the disease is predicted to double within 20 years. Despite significant progress in the field, medical science still has little to offer. Therefore, there is a critical need in new molecular targets, concepts, and approaches to treat this devastating disease.

miRNA, a class of small noncoding transcripts, regulates gene expression in various physiological and pathological conditions. miRNAs are important players in various cancers, acting as oncogenes and tumor suppressors (Hammond, 2006; Hwang and Mendell, 2006). In the mammalian nervous system, miRNA is known to play important roles in development, metabolism, and neural plasticity. Studies have shown that dysregulation of miRNA may play a role in several neurodegenerative diseases

Received March 27, 2013; revised June 27, 2013; accepted Aug. 3, 2013.

Author contributions: S.A., D.M.K., and A.M.K. designed research;S.A., D.M.K., and V.R. performed research;S.A., D.M.K., and A.M.K. analyzed data; S.A., D.M.K., and A.M.K. wrote the paper.

This work was supported by a grant from the Alzheimer's Association (NIRG-09-132844). The tissues were provided by the Harvard Brain Tissue Resource Center, which is supported in part by Public Health Service Grant number R 24MH 068855. We thank Michael Wolfe and members of the Krichevsky laboratory for valuable discussions. We also thank Hon-kit (Andus) Wong for help with transfection of mature neurons and Hyunje Grace Cho for technical assistance.

*S.A. and D.M.K. contributed equally to this work.

The authors declare no competing financial interests.

Correspondence should be addressed to Dr. Anna M. Krichevsky, Associate Professor of Neurology, Center for Neurologic Diseases, Brigham and Women's Hospital and Harvard Medical School, Harvard Institutes of Medicine, 77 Avenue Louis Pasteur, Boston MA 02115. E-mail: akrichevsky@rics.bwh.harvard.edu.

DOI:10.1523/JNEUROSCI.1327-13.2013

Copyright $\odot 2013$ the authors $\quad 0270-6474 / 13 / 3314645-15 \$ 15.00 / 0$
(Lau and de Strooper, 2010; Provost, 2010; Zovoilis et al., 2011) and some key $\mathrm{AD}$ proteins are predicted or validated as miRNA targets (Hébert et al., 2008, 2009; Vilardo et al., 2010; Zhu et al., $2012 \mathrm{~b}$ ); however, to date no evidence of miRNA-mediated regulation of $\mathrm{AD}$ progression has been demonstrated.

$\mathrm{AD}$ is a multifactorial disease characterized by $\mathrm{A} \beta$ deposition, tau hyperphosphorylation, oxidative stress, cholinergic deficits, progressive synaptic loss, and neurodegeneration. How all these typical characteristics of $\mathrm{AD}$ relate to each other is not clear. One of the earliest neuronal abnormalities in mild cognitive impairment (MCI) and AD is dysregulation of the cell cycle in postmitotic neurons, cells that are not normally cycling (Nagy et al., 1997; Vincent et al., 1997; Yang et al., 2001; Neve and McPhie, 2006; McShea et al., 2007; Bonda et al., 2010). Neuronal cell cycle regulatory failure presented by aberrant cell cycle entry (CCE) and often leading to cell death, may be a significant component of $\mathrm{AD}$ pathogenesis. Accumulating evidence suggests that CCE in neurons may precede tau and amyloid pathology, and that there is a link between CCE and tau-hyperphosphorylation (Andorfer et al., 2005; Park et al., 2007; Jaworski et al., 2009). A number of studies indicates that almost all neurons that exhibit tau pathology are also positive for various markers of cell cycle (Busser et al., 1998; Keeney et al., 2012; Seward et al., 2013).

In this study we identified a specific miRNA, miR-26b, whose levels rise at early stages of AD (Braak III, which usually corresponds to MCI) and remain elevated in the defined pathological areas of human AD brains during the disease progression. We demonstrate that overexpression (OE) of this miRNA in cultured postmitotic neurons leads to CCE. We validate tumor suppressor Retinoblastoma 1 (Rb1) as a prin- 
A

\begin{tabular}{ccclll}
\hline Age & Gender & PMI (hrs) & Diagnosis & Sample & Cases (n) \\
\hline $76.5 \pm 5.5$ & $5 \mathrm{M} / 3 \mathrm{~F}$ & $22.4 \pm 3.2$ & NDAR & Temporal cortex & 8 \\
$79.5 \pm 6.7$ & $3 \mathrm{M} / 7 \mathrm{~F}$ & $20.1 \pm 7.0$ & BraakllI & Temporal cortex & 10 \\
$81.0 \pm 6.2$ & $5 \mathrm{M} / 5 \mathrm{~F}$ & $18.1 \pm 8.3$ & BraakVI & Temporal cortex & 10 \\
\hline PMI: Post Mortem Interval & & & & \\
NDAR: No Diagnostic Abnormality Recognized & & & \\
All data are mean \pm standard deviation & & &
\end{tabular}

B

\begin{tabular}{|rcc|}
\hline miRNA & fold change & p-value \\
\hline \hline let7b & 1.146 & 0.302 \\
let7c & 1.536 & 0.018 \\
let7d & 1.911 & 0.209 \\
Let7i & 3.156 & 0.004 \\
miR-103 & 0.747 & 0.053 \\
miR-124a & 0.377 & 0.111 \\
miR-125a & 0.934 & 0.313 \\
miR-125b & 2.06 & 0.027 \\
miR-132 & 0.641 & 0.004 \\
miR-134 & 1.57 & 0.025 \\
miR-181a & 0.56 & 0.085 \\
\hline miR-26a & 2.041 & 0.023 \\
miR-26b & 2.483 & 0.006 \\
\hline mir-27a & 1.729 & 0.001 \\
miR-27b & 1.849 & 0.004 \\
miR-29a & 1.35 & 0.229 \\
miR-29c & 2.488 & 0.004 \\
miR-204 & 1.153 & 0.485 \\
miR-30a-5p & 1.819 & 0.005 \\
miR-7 & 2.238 & 0.051 \\
miR-9 & 0.947 & 0.451 \\
\hline & & \\
\hline
\end{tabular}

C
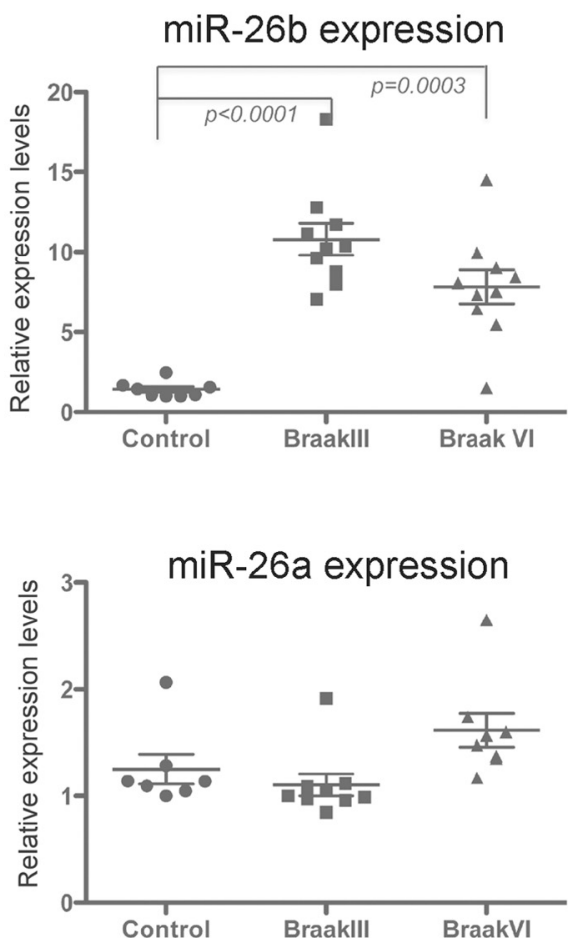

Figure 1. miR-26b expression is upregulated in AD. $A, A$ table summarizes information about the samples used in this study. $\boldsymbol{B}$, Multiplex miRNA expression analyses were performed on samples from temporal cortex of Braak III $(n=6)$ and control brains $(n=6)$. C, Expression of miR-26b (top) and miR-26a (bottom) was tested in control, Braak III, and Braak VI ( $n=8-10$ per condition) specimens by singleplex qRT-PCR, and relative levels calculated as $2^{-\Delta \mathrm{Ct}}$. Uniformly expressed miR-99a was used for normalization. Data represent mean \pm SEM with Mann-Whitney test.

cipal target that mediates miR-26b-induced CCE in neurons. Furthermore, both OE of miR-26b and inhibition of Rb1 cause activation of cyclin-dependent kinase $5(\mathrm{Cdk} 5)$ and increase tau phosphorylation at $\mathrm{AD}$-relevant epitopes, followed by apoptosis and neurodegeneration in culture. We propose that miR-26b upregulation, observed in $\mathrm{AD}$, perturbs signaling pathways associated with neuronal cell cycle, and thereby causes pleiotropic phenotypes associated with the disease. We propose that miR-26b has an important function in the pathophysiology of AD.

\section{Materials and Methods}

Materials. Frozen human postmortem brain specimens were obtained from Harvard Brain Tissue Resource Center and used in accordance with the policies of Brigham and Women's Hospital institutional review board.

Cell cultures and transfections. Primary cortical neurons were prepared from E18 Sprague Dawley rat embryos of either sex, and cultured in Neurobasal medium (Invitrogen) supplemented with $1 \times$ B27 (Invitrogen) as described previously (Krichevsky and Kosik, 2001).
Transfections of young neurons at day 2 in vitro (DIV2) with Rb1 siRNA (RB1RSS351663 or RB1RSS351662; Invitrogen), siRNA-E2F1 (sc-61861; Santa Cruz Biotechnology), pre-miR negative control 2 (AM17111; Ambion), pre-miR-26b (AM17100; Ambion) (50 nм), anti-miR-26b, or anti-miR-scramble (Dharmacon; $10 \mathrm{~nm}$ ) were performed with Lipofectamine 2000 (Invitrogen) according to the manufacturer's instructions. Transfections of mature (14-21 DIV) neurons were performed using NeuroMag (Oz Biosciences) according to manufacturer's instructions. The efficiency of transfections was $\sim 90-95 \%$ for both young and mature neurons as we previously demonstrated (Wong et al., 2013).

RNA isolation and analysis. Total RNA was extracted from frozen biopsy samples or cells using TRIZOL (Invitrogen) according to the manufacturer's instructions. Equal portions of white and gray matter from the temporal lobe were dissected and homogenized.

For miRNA analysis, TaqMan microRNA Reverse Transcription reagents and Universal PCR Master Mix with microRNA real-time PCR primers (Applied Biosystems) were used for qRT-PCR. For mRNA expression analysis, $1 \mu \mathrm{g}$ of total RNA was reverse-transcribed with TaqMan Reverse Transcription Reagents (Applied Biosystems N808-0234) and gene expression quantified using SYBR green (Applied Biosystems 
A

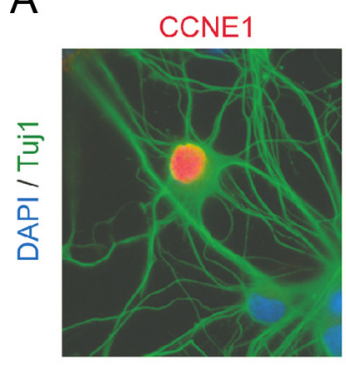

PCNA

Ki67
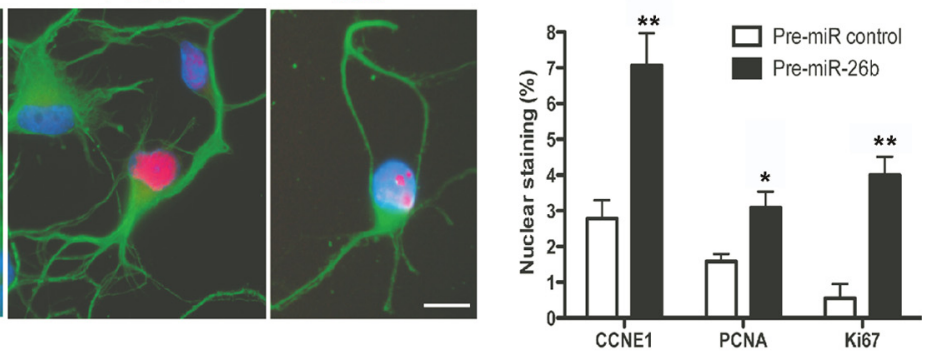

B
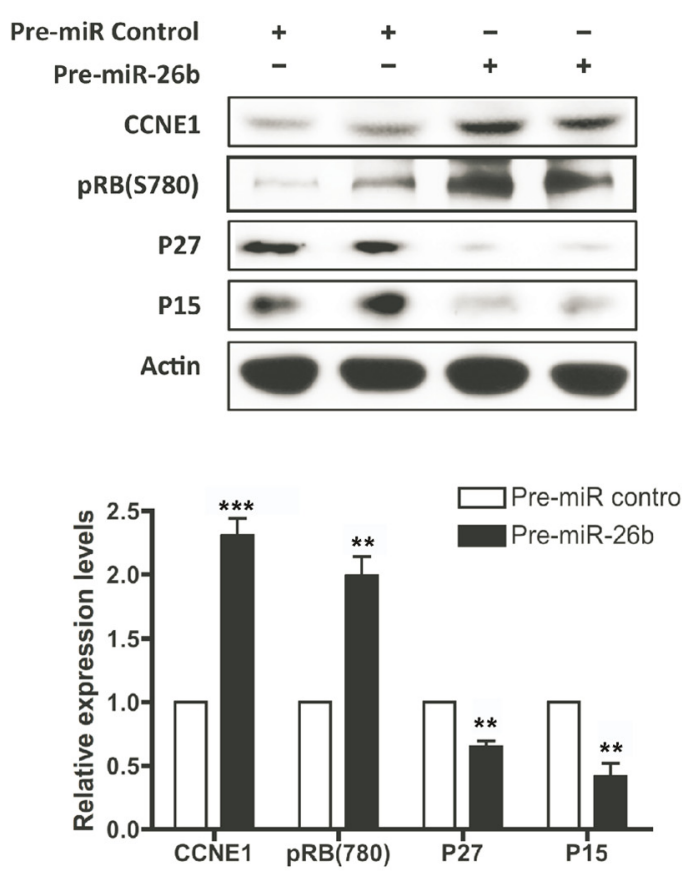

C

miR-26b
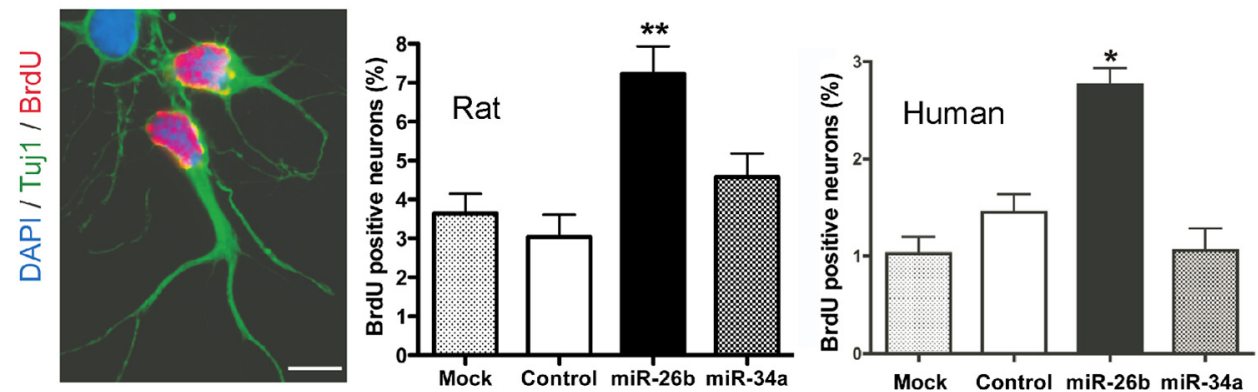

Figure 2. miR-26b OE induces cell cycle in primary postmitotic neurons. A, miR-26b OE in cortical neurons induces expression of CCNE1, PCNA, and Ki67 compared with neurons transfected with pre-miR control. Typical immunostainings are demonstrated. Histograms depict the number of Tuj1-positive neurons costained with the indicated nuclear markers $5 \mathrm{~d}$ post-transfection (Student's $t$ test, two-tailed ${ }^{*} p<0.05$ and ${ }^{* *} p<0.001 ; n=300$ neurons/condition). Scale bar, $10 \mu \mathrm{m}$. $\boldsymbol{B}$, Representative Western blot analysis and quantification of four independent experiments demonstrate effects of miR-26b 0E on positive (CCNE1 and ppRb1-Ser780) and negative (p27 and p15) regulators of cell cycle (Student's $t$ test, two-tailed ${ }^{* *} p<0.001$ and ${ }^{* * *} p<0.0001,5 \mathrm{~d}$ post-transfection). C, Analysis of BrdU incorporation in neurons by immunostaining for Tuj1 and BrdU demonstrates that 0E of miR-26b, but not a control miRNA or miR-34a, induces DNA replication in postmitotic cortical neurons. Representative immunostainings of BrdU ${ }^{+}$rat neurons are shown. Histograms depict the percentage of BrdU-positive rat (left) and human (right) neurons (Student's $t$ test, two-tailed $\left.{ }^{*} p<0.05, n=300\right)$. Scale bar, $10 \mu \mathrm{m}$.

SYBR Green PCR master mix). The sequences of primers used for qRTPCR analyses are available upon request.

Western blot. Western blot analysis was performed according to standard protocol as described previously (Gabriely et al., 2008). The following primary antibodies have been used in this study: against cleaved caspase 3 (9661S), Histone H3 (9175), Hsp90 (4874), p15 (4822), p27
(2552), pRb (S780) (9307), pRb(S807/811) (9308), Tau (S404) (44758G) Tau (S396) (44752G), and $\gamma$ H2A.X (9718) were obtained fromCell Signaling Technology. Antibodies against $\beta$-actin (ab8229), bromodeoxyuridine (BrdU) (ab6326), Ki67 (ab16667), and PCNA (ab29) were from Abcam. Antibodies against CCNA2 (sc-239), CCNE1 (sc-754), CDK5 (sc-6247 and sc-173), p35/25 (sc-820), pRb (sc-50), and E2F1 (sc-193) 
were from Santa Cruz Biotechnology. Antibody against Tau (S202)/ (T205) (44738G) was from Invitrogen, and Tuj1 (MMS-435P) was from Covance.

Human cortical neuron culture. Human fatal cortical tissues (gestational age 16 weeks), provided by Advanced Bioscience Resources were washed with DMEM. Meninges were removed and tissues cut into size of mouse/rat cortices $\left(\sim 3 \mathrm{~mm}^{3}\right)$ with forceps. Tissue was trypsinized in $0.25 \%$ trypsin and incubated at $37^{\circ} \mathrm{C}$ for $20 \mathrm{~min}$ with occasional swirling. Trypsin was removed and the tissue washed twice with $10 \mathrm{ml}$ of PR medium (DMEM with 10\% fetal bovine serum, 2 mM L-glutamine, $1 \mathrm{~mm}$ sodium pyruvate, and antibiotics). Tissue was triturated $5 \times$ with a $10 \mathrm{ml}$ plastic disposable pipette. Cell suspension was filtered through a $70 \mu \mathrm{m}$ followed by a $40 \mu \mathrm{m}$ cell strainer. Cells were spun at $1600 \mathrm{rpm}$ for $5 \mathrm{~min}$. Supernatant was removed and $1 \mathrm{ml}$ of PR medium was added to resuspend the cell pellet. PR medium was added and cells counted. Cells were plated in PR medium. Medium was replaced the next day (1 DIV) with PR and with Neurobasal at 5 DIV.

Validation of miR-26b target. miR-26b targets were validated using psiCHECK2 constructs (Promega C8021). Nucleotides 494-1156 of human $R b 1$ 3' UTR were cloned into psiCHECK2 using XhoI and NotI. Mutations were introduced into the wild-type constructs using QuikChange Multi Site-Directed Mutagenesis Kit (Stratagene 200514). For assessing miR-26b activity, psiCHECK2 luciferase reporter vector containing a single perfect miR-26b binding site downstream of luciferase open reading frame has been used. Luciferase luminescence was revealed with Dual-Glo Luciferase Assay System (Promega E2920) and detected with Infinite F200 plate reader (Tecan).

Terminal deoxynucleotidyl transferase-mediated biotinylated UTP nick end labeling assay. In Situ Cell Death Detection Kit, TMR red (Roche 12 156792 910) was used to reveal apoptotic cells. Cells were fixed in $4 \%$ paraformaldehyde (PFA) for $10 \mathrm{~min}$ at room temperature (RT) and permeabilized with $0.1 \%$ Triton X-100 in $0.1 \%$ sodium citrate for $2^{\prime}$ on ice. Cells were then incubated with terminal deoxynucleotidyl transferasemediated biotinylated UTP nick end labeling (TUNEL) reaction mixture for $1 \mathrm{~h}$ at $37^{\circ} \mathrm{C}$, immunostained with anti-Tuj1 (MMS-435P; Covance) and analyzed by fluorescence microscopy.

Cell viability assay. Luciferase/ATP-based assay (CellTiter-Glo Luminescent Cell Viability Assay; Promega G7571) was used according to the manufacturer's instructions. Cells were incubated with CellTiter-Glo reagent for $10 \mathrm{~min}$ at RT and luciferase signals were measured with the Infinite F200 (Tecan) plate reader. To measure cell viability of hydrogen peroxide-treated primary neurons, WST-1 assay (Roche 11644807001) was used according to manufacturer's instructions. Briefly, cells were incubated with WST-1 reagent at $1: 10$ dilution at $37^{\circ} \mathrm{C}$ for $1 \mathrm{~h}$, and absorbance was then measured at $440 \mathrm{~nm}$ with the Infinite F200 (Tecan) plate reader.

Immunocytochemistry. Cells were fixed in 4\% PFA in PBS at RT for $10 \mathrm{~min}$, permeabilized with $0.25 \%$ Triton $\mathrm{X}-100$ for $5 \mathrm{~min}$, and washed $(2 \times)$ with PBS. Cells were then blocked with $1 \%$ normal goat serum (NGS)-PBS for and incubated for $1 \mathrm{~h}$ at RT with primary antibody in $0.1 \%$ NGS-PBS. Cells were washed $(3 \times)$ with PBS and incubated with fluorescence-conjugated secondary antibodies at RT for $45 \mathrm{~min}$. Cells were washed $(3 \times)$ with PBS and mounted in Vectashield (Vector Laboratories) supplemented with DAPI and analyzed by fluorescent microscopy.

Cytoplasmic and nuclear fractionation. The procedure was performed according to (Bernocco et al., 2008). Cells were harvested in Buffer D (10 mм PIPES, pH 6.8, $100 \mathrm{~mm} \mathrm{NaCl}, 300 \mathrm{~mm}$ sucrose, $3 \mathrm{~mm} \mathrm{MgCl}_{2}, 5 \mathrm{~mm}$ EDTA, and $0.015 \%$ digitonin) with protease inhibitors (Complete Mini) and shaken for $15 \mathrm{~min}$ at $4^{\circ} \mathrm{C}$. After centrifugation at $5000 \times g$ for $10 \mathrm{~min}$ at $4^{\circ} \mathrm{C}$, the supernatant was collected and represented the cytosolic soluble protein fraction. The pellets were resuspended with Buffer T $(10 \mathrm{~mm}$ PIPES, pH 7.4, $100 \mathrm{~mm} \mathrm{NaCl}, 300 \mathrm{~mm}$ sucrose, $3 \mathrm{~mm} \mathrm{MgCl}_{2}, 3$ mм EDTA, and $0.5 \%$ Triton X-100) with protease inhibitors and shaken for $30 \mathrm{~min}$ at $4^{\circ} \mathrm{C}$. After centrifugation at $5000 \times g$ for $10 \mathrm{~min}$ at $4^{\circ} \mathrm{C}$, the pellet contained the nuclei that were washed twice with Buffer $\mathrm{T}$ and then lysed in Buffer C (10 mu PIPES, pH 7.4, $10 \mathrm{~mm} \mathrm{NaCl}, 1 \mathrm{~mm} \mathrm{MgCl}$, $1 \%$ Tween $40,0.5 \% \mathrm{DOC}$, and $1 \mathrm{U} / \mu \mathrm{l}$ benzonase) with protease inhibitors and
A

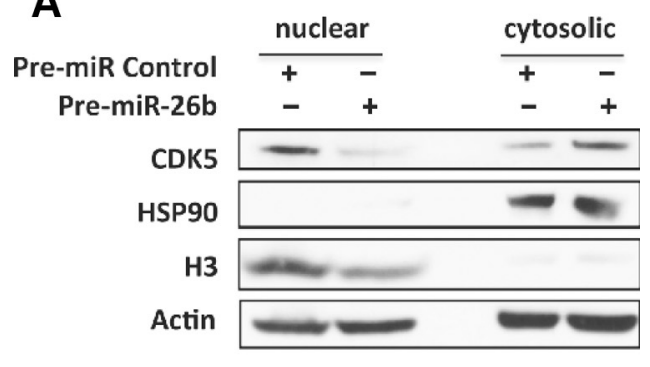

B

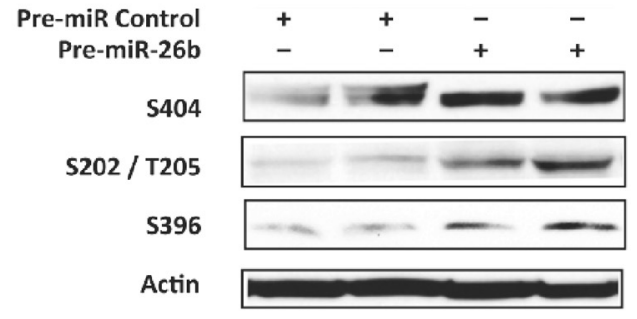

$\square$ Pre-miR control
Pre-miR-26b

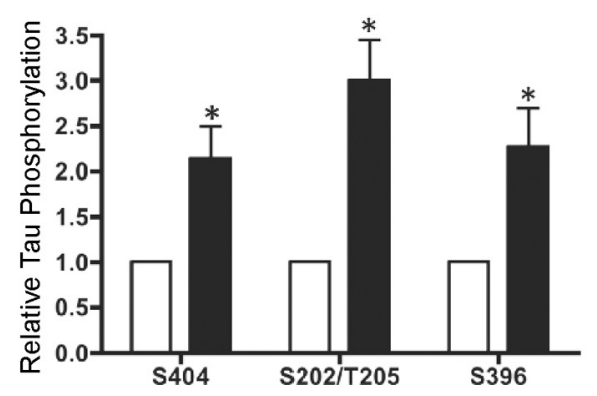

Figure 3. miR-26b OE leads to Cdk5 nuclear export and increased tau-phosphorylation in primary neurons. $\boldsymbol{A}$, Western blot analysis shows $(\mathrm{dk} 5$ reshuttling from the nuclear to the cytosolic fraction in miR-26b-overexpressing cortical neurons. Histone $\mathrm{H} 3$ and $\mathrm{Hsp} 90$ were used as markers of nuclear and cytosolic fractions, respectively, and actin as a loading control. $\boldsymbol{B}$, Western blot analysis shows that miR-26b 0E increases tau-phosphorylation at four different epitopes as compared with pre-miR control-transfected neurons. Quantification depicts the densitometric analysis of two experiments (Student's $t$ test, two-tailed ${ }^{*} p<0.05$ ).

shaken for $30 \mathrm{~min}$ at $4^{\circ} \mathrm{C}$. Centrifugation at $6800 \times g$ at $4^{\circ} \mathrm{C}$ for $30 \mathrm{~min}$ allowed the recovery of the supernatant as the nuclear fraction.

Immunoprecipitation. Cells were harvested $7 \mathrm{~d}$ after transfection in NP-40 lysis buffer (50 mm Tris-HCl, pH 7.4, 150 mm NaCl, 1 mм EDTA, $0.1 \%$ NP- 40 ) with protease inhibitors, and cell lysates prepared as described above. Cell lysates $(800 \mu \mathrm{g})$ were incubated with $1 \mu \mathrm{g}$ immunoprecipitating antibody for $1 \mathrm{~h}$ at $4^{\circ} \mathrm{C}$ and then incubated overnight at $4^{\circ} \mathrm{C}$ with $20 \mu \mathrm{l}$ anti-rabbit-IgG beads (eBioscience). Immunoprecipitated complexes were washed $(4 \times)$ with lysis buffer (centrifugation at $1000 \times$ $g$ at $4^{\circ} \mathrm{C}$ for $5 \mathrm{~min}$ ), recovered in $40 \mu \mathrm{l} 2 \times$ Laemmle buffer with $50 \mathrm{~mm}$ fresh dithiothreitol and boiled for $5 \mathrm{~min}$; samples were loaded onto SDSPAGE gels and analyzed by immunoblotting.

In vitro kinase assays. Immunoprecipitated complexes were washed $(2 \times)$ in NP-40 lysis buffer and in HEPES buffer (40 mM HEPES, pH 7.2, $8 \mathrm{mM} \mathrm{MgCl}_{2}$ ) and then used to phosphorylate $1 \mu \mathrm{g}$ Histone H1 (Millipore 14-155), Rb1 (769) (Santa Cruz Biotechnology sc-4112), or Tau 441 (151-421; SignalChem) peptides in $30 \mu$ l kinase buffer $(40 \mathrm{~mm}$ HEPES, pH 7, 8 mM $\mathrm{MgCl}_{2}, 125 \mathrm{~nm}$ okadaic acid, protease inhibitors, and $10 \mathrm{~mm}$ ATP). After incubation for $1 \mathrm{~h}$ at $37^{\circ} \mathrm{C}$, the reactions were stopped by adding $2 \times$ Laemmle buffer and boiling for $5 \mathrm{~min}$, and the analysis was performed by Western blotting for phospho-Rb (780) (9307; Cell Signaling Technology), phospho-Histone H1 (T146) (ab3596; Abcam), and phospho-Tau (S404) (44758G; Cell Signaling Technology). 
A

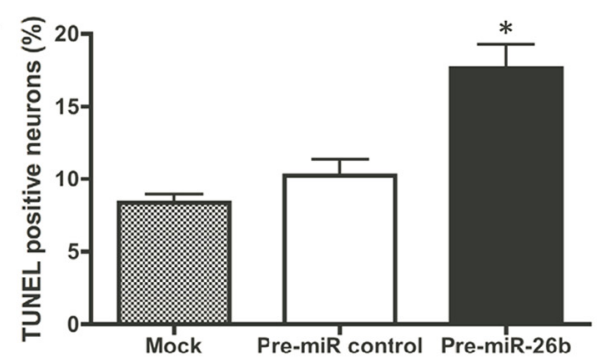

B

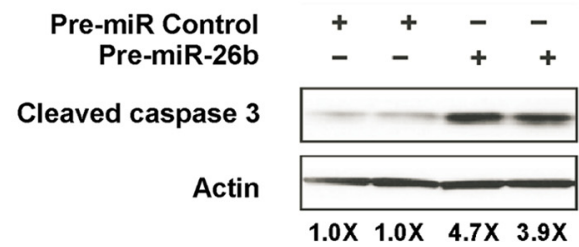

C
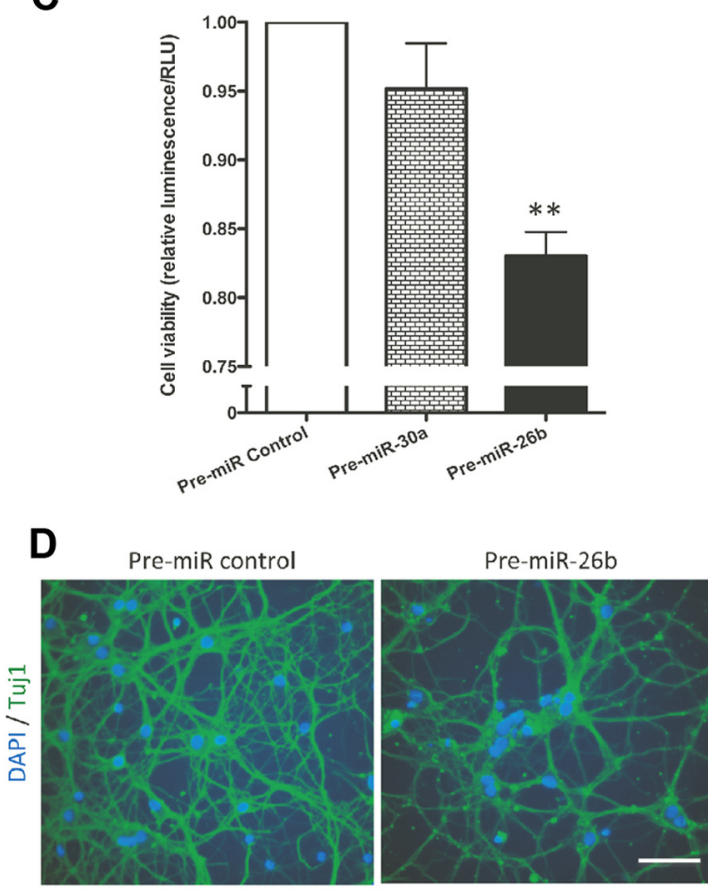

E

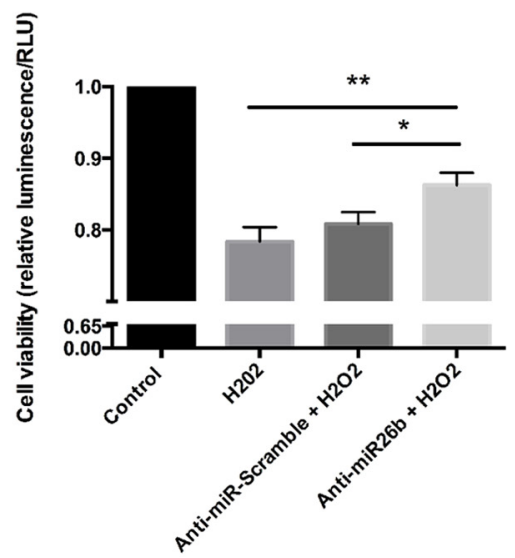

Figure 4. Primary neurons overexpressing miR-26b show evidence of apoptosis and reduced cell viability. $\boldsymbol{A}$, Histograms depict the percentage of TUNEL-positive neurons $5 \mathrm{~d}$ posttransfection (Student's t test, two-tailed ${ }^{*} p<0.05, n=3,300$ neurons/condition). $\boldsymbol{B}$, Western blot analysis and quantification showing that $0 \mathrm{E}$ of pre-miR-26b leads to an increase in caspase

\section{Results}

miR-26b is upregulated in human MCI and AD

Using multiplex real-time qRT-PCR, we profiled miRNA expression in defined pathological areas of human $\mathrm{MCI}$ and $\mathrm{AD}$ brains along with similar regions of aged-matched healthy brains. RNA was isolated from frozen temporal cortex, a region susceptible to $\mathrm{AD}$, of individuals with MCI (Braak III), severe AD (Braak VI), and nonpathological brains $(n=8-10$ per group; Fig. $1 A)$. Expression analysis was performed for a set of 21 selected miRNAs, highly abundant in brain regions susceptible to $\mathrm{AD}$. This analysis suggested several miRNAs as significantly dysregulated in Braak III cases compared with the control group (Fig. 1B). The analysis of Braak III tissues was not skewed by the differential representation of neurons versus glia since there is no significant neural loss at Braak III stage of the disease. More specific singleplex qRTPCR miRNA expression analyses confirmed the most significant increase in the expression of miR-26b (but not of its paralog miR-26a) in both Braak stages III and VI (Fig. 1C). A previous report by Cogswell et al. (2008) suggested upregulation of both miR-26a and miR-26b in hippocampi but not cerebellum of Braak III/IV patients. The data we present here, using more specific singleplex qRT-PCR, has validated that only one member of the miR-26 family, miR-26b, is elevated significantly in MCI and $\mathrm{AD}$. This is in contrast with the other reported screens of miRNA dysregulation in $\mathrm{AD}$, which have not detected upregulation of miR-26b (Wang et al., 2011; Satoh, 2012). This discrepancy is likely due to the less specific character of the platforms used in other studies and to cross-hybridization between the probes for miR-26a (not altered) and miR-26b. Since other deregulated miRNAs identified in our screen (e.g., let-7i and miR-29c) belong to larger miRNA families that include multiple members, and thus assessing their specific functions will be challenging, and our pilot experiments suggested the most interesting and consistent phenotype for miR-26b, we focused in this study on miR-26b functions and its potential role in the $\mathrm{AD}$ neuropathology. A role of another significantly deregulated miRNA, miR-132, in AD and other neurologic disorders has been investigated previously (Smith et al., 2011; Wong et al., 2013).

\section{miR-26b OE induces cell cycle in postmitotic neurons}

Several studies reported that miR-26 regulated cell cycle in dividing cells (Huse et al., 2009; Kota et al., 2009; Kim et al., 2010; Lu et al., 2011; Dill et al., 2012). Since reactivation of cell division and failure in cell cycle regulatory mechanisms are some of the earliest neuronal abnormalities in the AD brains, we hypothesized that this might be due to the increased miR-26b expression. To study the effects of miR-26b upregulation on neuronal cells, we used a gain-of-function approach and transfected E18 postmitotic cortical cultures with synthetic miR-26b mimic molecules (pre-mir26b). When transfected at $50 \mathrm{~nm}$, pre-miR-26b led to increased miR-26b levels and elevated its endogenous activity in neurons 3-

\section{$\leftarrow$}

3 cleavage in postmitotic neurons (Student's $t$ test, two-tailed ${ }^{*} p<0.01, n=3$ ). C, Cell viability of neurons analyzed by ATP-based assay $5 \mathrm{~d}$ post-transfections of pre-miR-26b, premiR-30a, or pre-miR control (Student's t test, two-tailed ${ }^{* *} p<0.001, n=3$ ). $\boldsymbol{D}$, Representative images of neurons transfected with pre-miR-26b or pre-miR control and stained for Tuj1, $7 \mathrm{~d}$ post-transfection. Scale bar, $50 \mu \mathrm{m}$. E, miR-26b inhibition protects primary neurons against hydrogen peroxide-mediated cytotoxicity. Cell viability of neurons was measured using WST-1 reagent $5 \mathrm{~d}$ post-transfection of anti-miR-26b or anti-miR-scramble and $14-16 \mathrm{~h}$ post $\mathrm{H}_{2} \mathrm{O}_{2}$ treatment (Student's $t$ test, two-tailed ${ }^{* *} p<0.005,{ }^{*} p<0.05, n=4$ with quadruplicate in each experiment). 


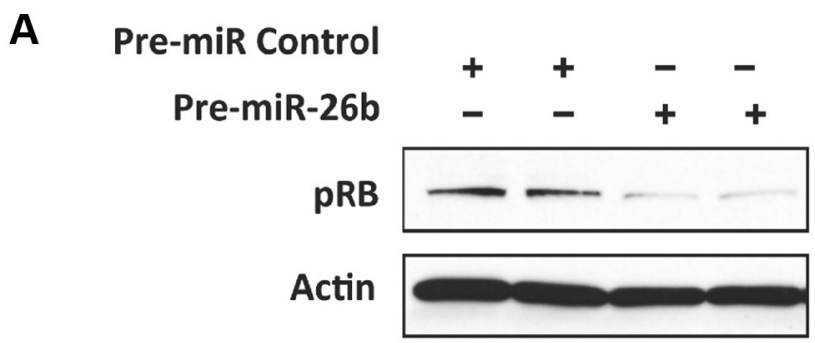

B

\begin{tabular}{|c|c|}
\hline & pRB1 3’ UTR (nt 800-822) \\
\hline $\operatorname{miR}-26 b$ & $\begin{array}{l}\text { UGGAUAGGACUUAAUGAACUU } \\
\text { | | | | | ||||||| }\end{array}$ \\
\hline H.Sapiens & AAAGUACCCAUCUAGUACUUGAA \\
\hline P.Troglodytes & AAAGUACCCAUCUAGUACUUGAA \\
\hline M.Mulatta & AAAGUACUCAUCUAGUACUUGAA \\
\hline M.Musculus & AAGUACCCAUGUAGUACUUGAA \\
\hline \multirow[t]{3}{*}{ R.Norvegicus } & AAGUACCCAUGUAGUACUUGAA \\
\hline & Site 2 (7mer-1A) \\
\hline & pRB1 3' UTR (nt 1063-1083) \\
\hline $\operatorname{miR}-26 \mathrm{~b}$ & UGGAUAGG-ACUUAAUGAACUU \\
\hline & $\|||||||||||||$ \\
\hline H.Sapiens & GUCU-UCCAUGUAUCUUUUGAA \\
\hline P.Troglodytes & GUCU-UCCAUGUAUCUUUUGAA \\
\hline M.Mulatta & GUCU-UCCAUGUAUCUUUUGAA \\
\hline M.Musculus & UCU-UCCAGG-GUCUUUUGAA \\
\hline R.Norvegicus & GUCU-UCCAGG-GUCUUUUGAA \\
\hline
\end{tabular}
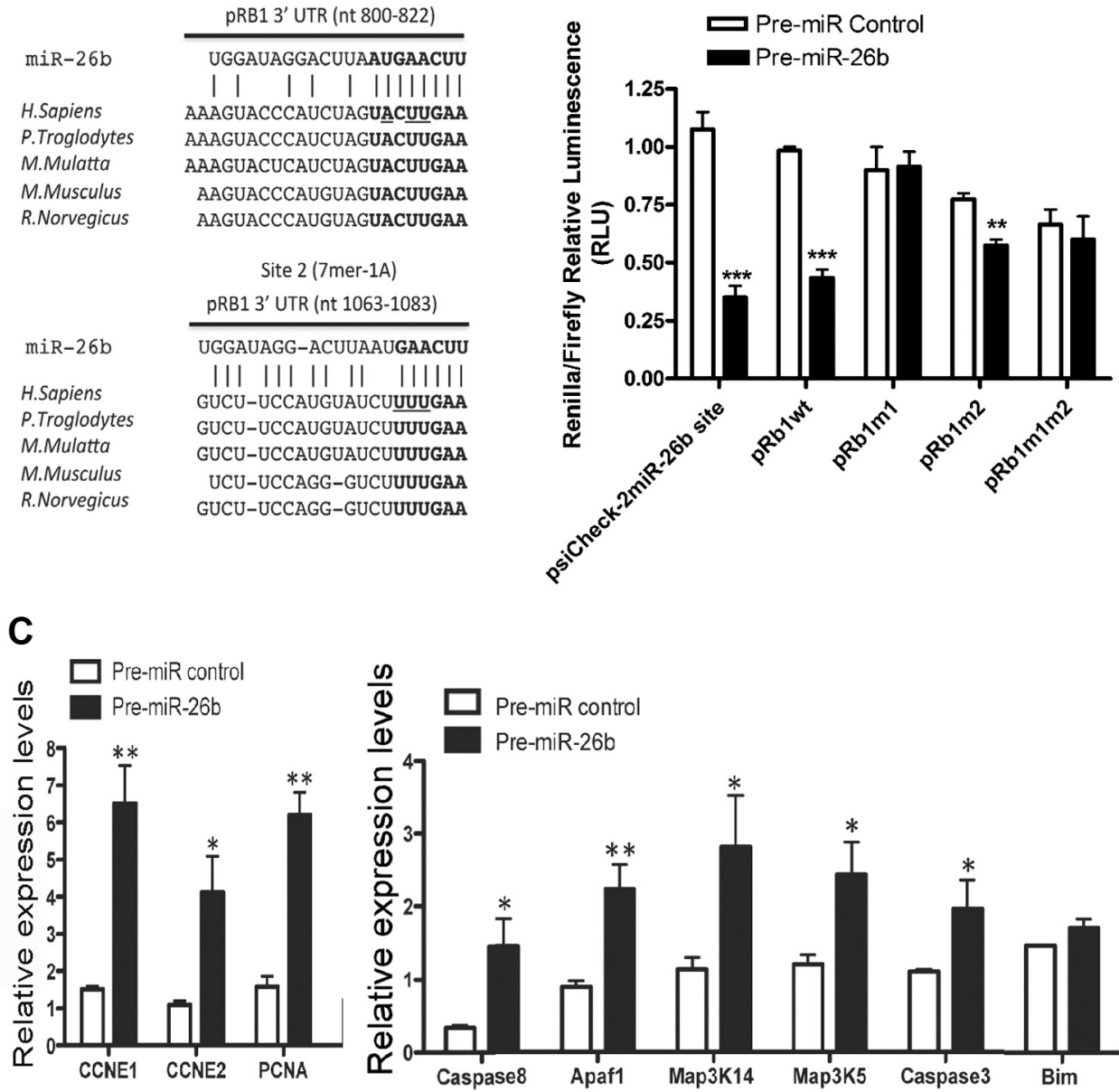

D

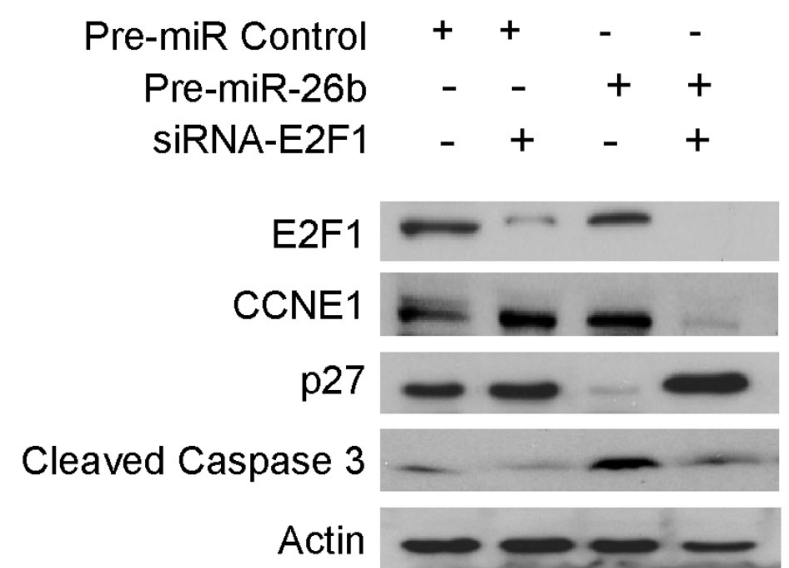

Figure 5. Retinoblastoma is a direct target of miR-26b. $A$, Western blot analysis shows that miR-26b OE downregulates Rb1 protein in cortical neurons $72 \mathrm{~h}$ post-transfection (Student's $t$ test, two-tailed ${ }^{* * *} p<0.0001, n=3$ ). B, Predicted conserved miR-26b binding sites within the Rb1 $3^{\prime}$ UTR are shown (left). The nucleotides mutated in the Rb1 $3^{\prime}$ UTR for the luciferase reporter assays are underlined. Relative luciferase reporter activity of cognate miR-26b reporter (left two bars: psiCheck-2 miR-26b site), wild-type (wt), or mutant (m) (Figurelegend continues.) 
to 4 -fold, as indicated by the activity of miR-26b luciferase reporter (Fig. $5 B$, right, first two bars).

To test the effects of miR-26b on neurons, the cells transfected with pre-miR-26b or a scrambled pre-miR control, were harvested $5 \mathrm{~d}$ after transfection and subjected to immunostaining for various cell cycle and proliferation markers. MiR-26b OE significantly increased the nuclear staining of cyclin E1 (CCNE1), PCNA (DNA polymerase processivity factor), and Ki67 in postmitotic (Tuji+) neurons (Fig. 2A). Ki67, a marker of proliferative cells, was nearly undetectable in neurons treated with the control oligo, and detected in $4 \%$ Tuj $1^{+}$neurons in the miR-26b transfected cultures. The characteristic pattern of Ki67 staining suggested that neurons were in $G_{1}$ and $S$ phases but never proceeded to $\mathrm{G}_{2} / \mathrm{M}$. These results indicate that elevated expression of miR26b, also observed in MCI and AD cases, can induce CCE in postmitotic neurons. To confirm this, we transfected primary rat cortical neurons with pre-miR-26b or a scrambled pre-miR control and performed Western blot analysis for several regulators of cell cycle such as CCNE1 and phosphorylated pRb (ppRB), often observed in AD neurons (Jordan-Sciutto et al., 2002; de las Cuevas et al., 2003). OE of miR-26b led to a significant increase in the expression of CCNE1, and ppRb, and a decrease in the cell cycle inhibitors p27 and p15 (Fig. 2B). To further confirm that miR$26 \mathrm{~b}$ was inducing CCE in postmitotic neurons we performed a $\mathrm{BrdU}$ incorporation assay. Our results demonstrate that $\mathrm{OE}$ of miR-26b significantly increases BrdU incorporation in both rodent and human Tuji ${ }^{+}$neurons. This increase in BrdU incorporation was specific for miR-26b OE as a control miRNA and also miR-34a (another miRNA abundant in the brain, and involved in both regulation of cell cycle in proliferative cells and neurodegeneration; Bommer et al., 2007; Hermeking, 2009; Liu et al., 2012) had no effect (Fig. 2C). Glial GFAP ${ }^{+}$cells that typically constitute $<5 \%$ of our rodent primary cultures and $\sim 40-50 \%$ of human primary cultures were not affected by miR-26b OE (data not shown).

\section{miR-26b OE induces Cdk5 reshuttling and tau- phosphorylation}

Inhibition of cell cycle in postmitotic neurons is exerted by a nuclear complex consisting of p27 and Cdk5. Cdk5 is an atypical kinase that, when localized to nucleus, plays a central role in this process (Zhang et al., 2008; Zhang and Herrup, 2008). Cdk5 does not have an intrinsic nuclear localization signal and its nuclear localization relies on its binding to the cyclin-dependent kinase inhibitor p27. In the absence of p27, Cdk5 is exported to cytoplasm, where it can no longer suppress the cell cycle (Zhang et al., 2010). Cytosolic Cdk5 is also well characterized as a major tau

\footnotetext{
(Figure legend continued.) psiCHECK-2-Rb13'UTR constructs cotransfected with a precursor pre-miRNA control or pre-miR-26b $(50 \mathrm{~nm})$ in cultures of rat primary neurons (right). $\mathrm{OE}$ of miR-26b led to a significant decrease in the relative activity of a wt but not mutated at site 1 construct, as compared with cells transfected with the pre-miR control (Student's $t$ test, twotailed ${ }^{* *} p<0.001$ and ${ }^{* * *} p<0.0001, n=3$; error bars indicate SEM from 3 independent transfections). C, qRT-PCR analysis of E2F transcriptional targets associated with cell cycle (CCNE1, CCNE2, and PCNA, left) and apoptosis (Caspase 8, Apaf1, Map3K14, Map3K5, Caspase 3, and Bim, right). The quantification reflects expression changes observed $5 \mathrm{~d}$ after transfection with pre-miR-26b relative to control. GAPDH served as a normalization housekeeping gene (Student's $t$ test, two-tailed, ${ }^{*} p<0.05,{ }^{* *} p<0.001, n=3$ ). D, E2F1 downregulation abolishes key effects of miR-26b $0 E$. Western blot analysis of neurons cotransfected with siRNA-E2F1 and either pre-miR-26b or pre-miR control demonstrates a decrease in CCNE1 and cleaved caspase 3 and an increase in $\mathrm{p} 27$ in neurons cotransfected with siRNA-E2F1 and pre-miR-26b $5 \mathrm{~d}$ post-transfection.
}

kinase (Lee and Tsai, 2003; Mazanetz and Fischer, 2007). Since miR-26b transfections significantly reduced the levels of p27 in neurons, we tested how they affected Cdk5 intracellular localization. MiR-26b or pre-miR control were transfected into primary neurons followed by cytoplasmic/nuclear fractionation. Western blot analysis revealed that OE of miR-26b caused the export of Cdk5 from the nucleus to the cytoplasm (Fig. 3A).

Interestingly, the vast majority of neurons with neurofibrillary tangles (NFT) in AD brains are also positive for cell cycle markers (Busser et al., 1998), suggesting a common regulation or a link between CCE and tau aggregation. Since miR-26b affects cellular localization of Cdk5, a major tau kinase, we tested how OE of miR-26b affects tau phosphorylation in postmitotic neurons. Western blot analyses revealed a statistically significant increase in tau phosphorylation at several sites, including pS202/T205 (AT8) and pS396/S404 (PHF-1), Cdk5 phosphorylation sites typical for early and late NFTs, respectively, in AD (Fig. 3B).

\section{miR-26b OE leads to apoptotic cell death of primary neuronal cultures}

Induction of cell cycle in neurons, and also Cdk5 reshuttling often lead to (and may even cause) neuronal death (Byrnes et al., 2007; Fu et al., 2013). Importantly, the observed CCE and tau hyperphosphorylation in miR-26b overexpressing neurons were followed by apoptotic cell death as indicated by immunostaining and TUNEL experiments (Fig. 4A,D). This effect was sequence specific as neurons transfected with pre-miR control and other miRNA mimics did not cause an increase in apoptosis above the background levels observed in mock-transfected cultures. Furthermore, the levels of activated (cleaved) caspase 3, the major effector of neuronal apoptosis associated with $\mathrm{AD}$, were significantly increased in neurons transfected with pre-miR-26b (Fig. $4 B)$. OE of miR-26b led to a significant sequence-dependent decrease in neuronal cell viability, as assessed by an ATP-based metabolic activity assay (Fig. 4C). Finally, we investigated if miR26b knockdown could have a neuroprotective effect following an AD-relevant apoptotic stimulus. We used hydrogen peroxide treatment, an established experimental system for studying oxidative stress-induced neurodegenerative response, which also activates CCE in postmitotic neurons (Schwartz et al., 2007). Primary cortical neurons were transfected with sequence-specific miR-26b inhibitor (anti-miR-26b) or an anti-miR-scramble control molecule, and then exposed to $15 \mu \mathrm{M} \mathrm{H}_{2} \mathrm{O}_{2}$ overnight. As shown in Figure $4 E$, miR-26b inhibition led to a significant increase in cell viability of hydrogen peroxide-treated primary neurons. Since the miR-26b's paralog miR-26a could potentially compensate for the reduced miR-26b activity, more potent inhibition of both miR-26a and $-26 \mathrm{~b}$ might be used to further enhance the neuroprotection.

\section{miR-26b directly regulates expression of $\mathrm{Rb}$ protein in neurons and affects Rb1/E2F transcriptional targets}

To identify principal targets that mediate miR-26b effects in neurons, we used several target prediction algorithms, and found two putative highly conserved binding sites within the Rb 3' UTR (Fig. $5 B$ ). Retinoblastoma is a potent tumor suppressor that controls cell cycle at the $\mathrm{G}_{1}$-to-S phase checkpoint, primarily by inhibiting E2F transcription factors and thereby hampering the transcription of genes required for transition to S-phase (Sellers et al., 1995; Smith et al., 2000). In neuronal cells, Rb protein likely plays a crucial role in cell survival and its phosphorylation is tightly correlated with neuronal death (Galderisi et al., 2003; Greene et al., 2004; Andrusiak et al., 2012). In addition, Rb/E2f 
A

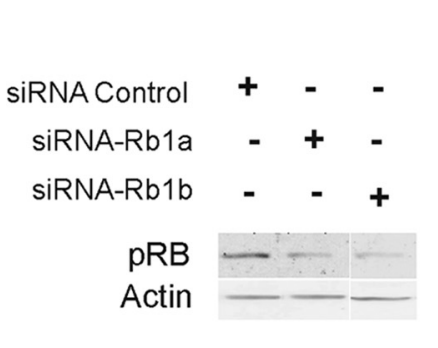

B

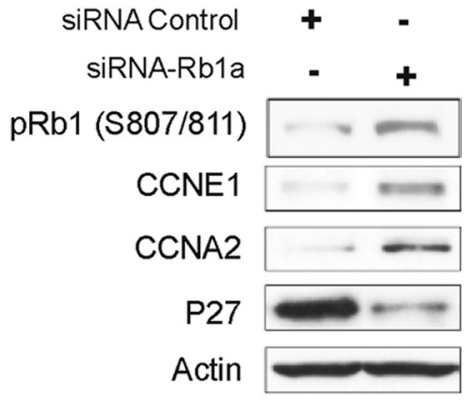

C
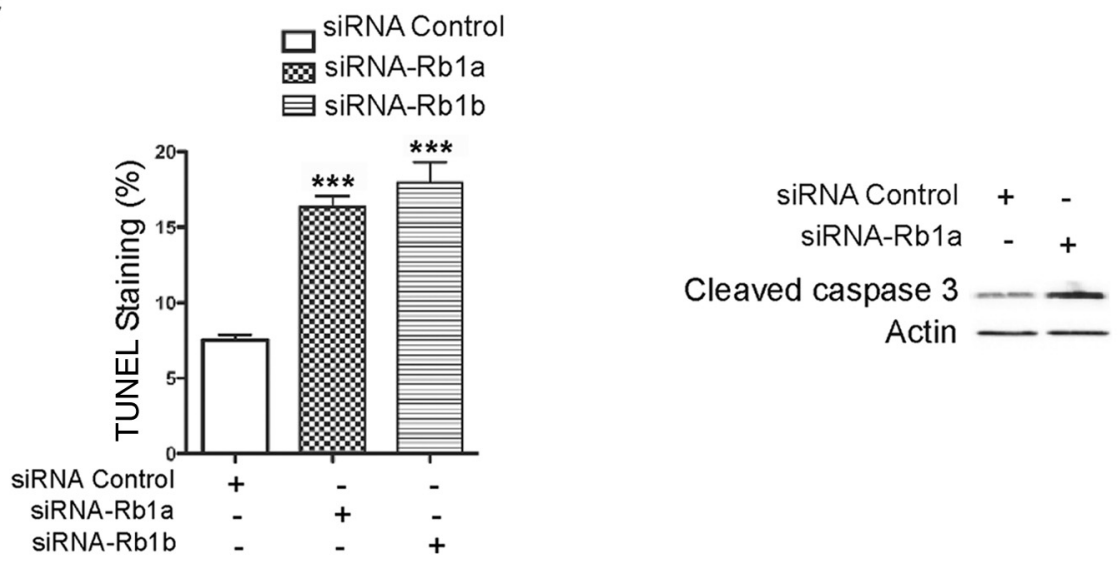

D

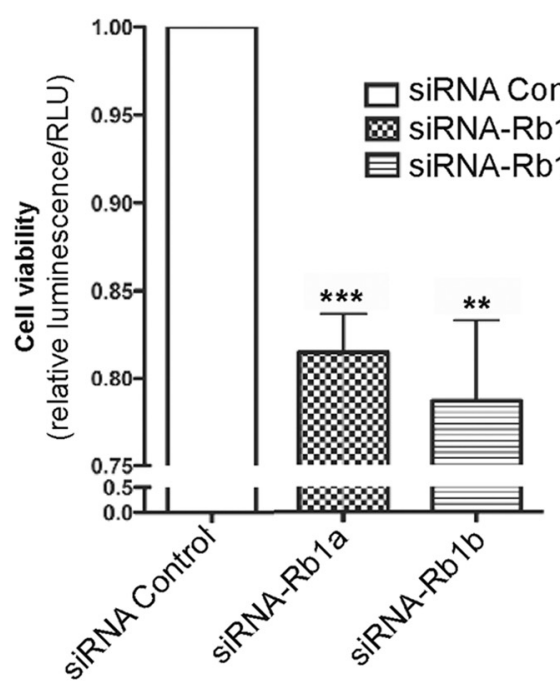

E
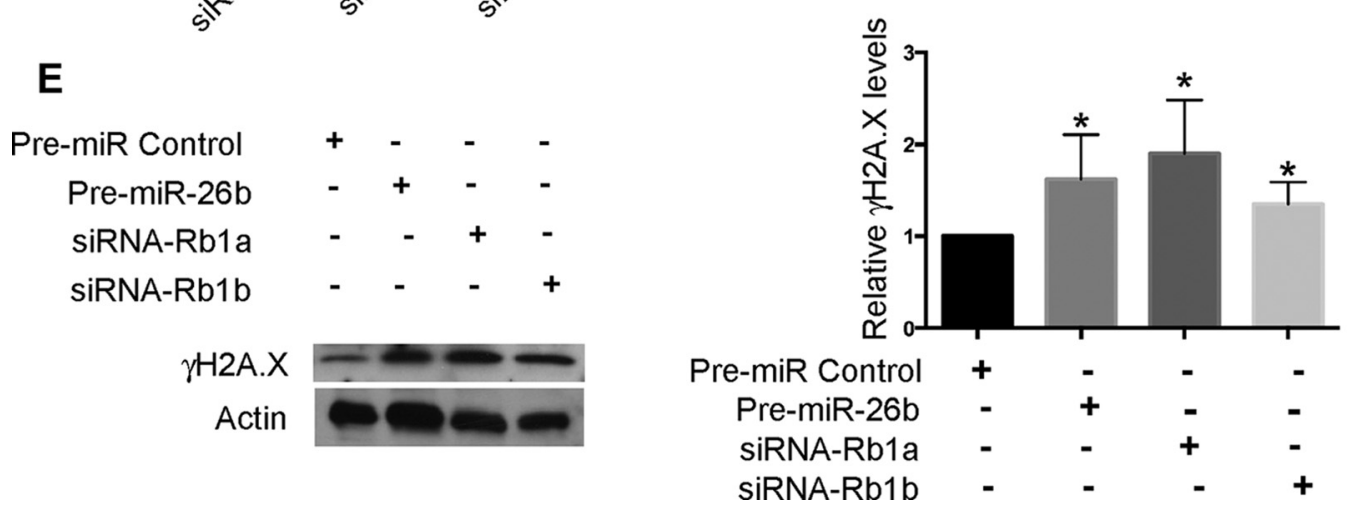

Figure 6. Retinoblastoma downregulation in primary cortical neurons by RNAi leads to induction of cell cycle and apoptosis, and mimics the miR-26b OE phenotype. $A$, Western blot analysis shows that two different siRNAs for Rb1 (siRNA-Rb1a and siRNA-Rb1b) efficiently reduce pRb1 expression $72 \mathrm{~h}$ post-transfection (left). Transfections of neuron cultures (Figure legend continues.) 
signaling has been implicated in the regulation of gene expression in AD (Ranganathan et al., 2001; Muñoz et al., 2005). Western blot analysis demonstrated that miR-26b OE in primary neurons led to substantial reduction of $\mathrm{Rb}$ levels (Fig. 5A).

To confirm that $\mathrm{Rb}$ mRNA was a direct target of miR-26b, we constructed luciferase reporter plasmids that contained either the wild-type $3^{\prime}$ UTR sequence of Rb mRNA or one in which the miRNA-binding sites have been mutated (Fig. 5B). Using these reporters, we validated that miR-26b directly binds to the $3^{\prime} \mathrm{UTR}$ of $\mathrm{Rb}$ mRNA and represses its expression in primary neurons (Fig. 5B). This repression was abolished by mutations in one of two predicted miR-26b binding sites within Rb 3'UTR. These results indicate that miR-26b directly regulates expression of $\mathrm{Rb}$.

E2F family of transcription factors is a key downstream effector of the $\mathrm{Rb}$ activity; reduced levels of $\mathrm{Rb}$ lead to the derepression of E2F-driven transcription and thus upregulation of E2F transcriptional targets, including both cell cycle and proapoptotic genes. To investigate if OE of miR-26b regulates E2F targets, we transfected either pre-miR-26b or a pre-miR control into primary neurons and performed qRT-PCR analysis of known E2F transcriptional target genes, such as cell cycle regulators CCNE1, CCNE2, and PCNA and the regulators of apoptosis APAF1, MAP3K5, Caspase 8, and Caspase 3. Remarkably, OE of miR-26b in neurons led to a significant upregulation of the majority of investigated E2F targets, including both S-phase and pro-apoptotic genes (Fig. 5C). Of note, Bim, an important mediator of apoptosis, transcriptionally regulated by several factors including E2F1, was not affected by miR-26b OE.

To further confirm that miR-26b regulation is mediated through the E2F1 transcription machinery, we simultaneously overexpressed miR-26b and downregulated E2F1 by the cognate siRNA. We observed that E2F1 silencing abolished miR-26binduced elevation of CCNE1, downregulation of p27, and most importantly it rescued neurons from apoptosis, as suggested by the levels of cleaved caspase 3 (Fig. 5D).

Since there are many important E2F1 targets regulated by miR-26b, it may not be practical to attribute observed cell death to a specific gene(s) involved in apoptosis versus cell cycle pathway. Nevertheless, we argue that miR-26b-induced CCE is unlikely to be merely a coincident event for the following reasons: (1) it is established by numerous publications that induction of CCE in postmitotic neurons is tightly linked and can lead to cell death in various systems, even in the absence of transcriptional induction of apoptotic genes (Park et al., 2007; Andrusiak et al., 2012); (2) in our system, induction of proliferative markers Ki67 and PCNA was an early event observed $3 \mathrm{~d}$ post miR-26b transfection; and (3) one of the most pronounced effects of miR-26b

\footnotetext{
(Figure legend continued.) with these siRNAs lead to increased nuclear staining for both Ki67 and PCNA (right). Histograms depict the percentage of Tuj $1{ }^{+}$neurons with the corresponding nuclear staining, counted $5 \mathrm{~d}$ post-transfection (Student's $t$ test, two-tailed, ${ }^{*} p<0.05, n=$ 300 neurons). $\boldsymbol{B}$, Western blot analysis demonstrates an increase in the expression of cell cycle markers CCNE1 and ppRb1 (S807/811) and a decrease in the expression of the cell cycle inhibitor p27 5 d post-transfection with siRb1. C, Histograms depict the percentage of TUNEL-positive Tuj $1{ }^{+}$neurons 5 d post-transfection (Student's $t$ test, two-tailed, ${ }^{* * *} p<0.0001, n=300 / 3$ ). Western blot analysis (right) shows upregulation of cleaved caspase 3 after transfection with siRb1. D, Cell viability assay demonstrates reduced viability of postmitotic neurons transfected with two siRNAs cognate to Rb1, 5 d post-transfection (Student's $t$ test, two-tailed, ${ }^{* *} p<$ 0.001 and ${ }^{* * *} p<0.0001, n=3$ ). $E$, Western blot analysis (left) of $\gamma \mathrm{H} 2 \mathrm{~A} . \mathrm{X} 5 \mathrm{~d}$ after transfections of pre-miR-Control, pre-miR-26b, siRNA-Rb1a, or siRNA-Rb1b. Quantification of relative $\gamma$ H2A.X levels shows a significant increase in experimentally transfected neurons as compared with pre-miR control transfected (Student's $t$ test, two-tailed, ${ }^{*} p<0.05, n=4$ ).
}

OE was strong downregulation of the cell cycle inhibitor p $27^{\text {kip } 1 \text {, }}$ the event sufficient to induce death of cortical neurons in vitro and in vivo (Akashiba et al., 2006; Ye and Blain, 2010).

\section{Downregulation of $\mathrm{Rb}$ mimics the effects of miR-26b on cell cycle and apoptosis in neurons}

To assess whether $\mathrm{Rb}$ is the major miR-26b target that mediates miR-26b phenotype observed in primary neurons, we investigated if downregulation of $\mathrm{Rb}$ by RNAi mimics the effects of miR-26b OE on cell cycle and apoptosis in neurons. Importantly, the siRNAs deployed in this study reduced target Rb mRNA levels by a magnitude comparable to that previously observed to be elicited by ectopic miR-26b expression in these same cells $(\sim 2-$ fold at $48-72 \mathrm{~h}$ post-transfection; Fig. $6 \mathrm{~A}$, left); thus, RNAi approach allowed us to reasonably approximate the consequences of miR-26b's action on this effector molecule. Cortical neurons were transfected with either different siRNAs cognate to $\mathrm{Rb}$ mRNA or a control siRNA. Five days after transfection the cells were subjected to immunostaining for the cell cycle markers PCNA and Ki67. As expected, downregulation of Rb by siRNAs increased the nuclear staining of both PCNA and Ki67, indicating CCE similar to that observed in miR-26b overexpressing cells (Fig. 6A). In parallel, Western blot analyses of cells transfected with $\mathrm{Rb}$ siRNA revealed an increase in CCNE1 and phosphorylated $\mathrm{Rb}$, and a decrease in $\mathrm{p} 27$ (Fig. $6 \mathrm{~B} ; 120 \mathrm{~h}$ post-transfection), similar to those observed in miR-26b OE conditions. Of note, since direct downregulation of $\mathrm{Rb}$ expression by either cognate siRNA or miR-26b OE (observed at protein level $72 \mathrm{~h}$ posttransfection) leads to the increased phosphorylation of the remaining $\mathrm{Rb}$ protein at a later time point $(120 \mathrm{~h})$, this suggests that increased phosphorylation of $\mathrm{Rb}$ in the miR-26b-overexpressing cells (Fig. $2 B$ ) is a secondary effect, caused by miR-26b targeting and repression of $\mathrm{Rb}$.

Furthermore, downregulation of Rb by siRNAs caused an increase in cleaved caspase 3 and led to a significant increase in the number of TUNEL-positive apoptotic neurons (Fig. 6C). Finally, analysis of cell viability by a luciferase/ATP-based assay $7 \mathrm{~d}$ after transfection with siRNA-Rb, or a control RNA duplexes demonstrated that, similarly to OE of miR-26b, knockdown of Rb leads to a significant decrease in neuronal cell viability (Fig. 6D).

Reports have shown that cell cycle induced by $R b 1$ deficiency leaves cells more susceptible to DNA damage (Manning and Dyson, 2011). To evaluate miR-26b-overexpressing or Rb1deficient neurons for the presence of DNA damage, we assessed them for $\gamma \mathrm{H} 2 \mathrm{AX}$, a histone $\mathrm{H} 2 \mathrm{AX}$ phosphorylation at serine 139 and marker for DNA damage induced by double-strand breaks (Rogakou et al., 1998). Transfections with pre-miR-26b, as well as siRNAs-Rb1, all led to an increase in the levels of $\gamma \mathrm{H} 2 \mathrm{AX}$ (Fig. $6 E$ ), suggesting that $\mathrm{Rb} 1$ inhibition and the downstream CCE may activate the DNA damage pathway.

\section{miR-26b OE and $\mathrm{Rb}$ repression lead to tau-phosphorylation and an increase in Cdk5 activity}

We next sought to determine whether, like miR-26b OE, downregulation of Rb by RNAi could also lead to an increase in tauphosphorylation. Primary cortical neurons were transfected with siRNA-Rb or control RNA duplex and subjected to Western blot analysis $5 \mathrm{~d}$ post-transfection. SiRNA-mediated knockdown of Rb led to a statistically significant increase in tau-phosphorylation at S202/T205 (AT8) and S404 (PHF-1), Cdk5 phosphorylation sites typical for early and late NFTs, respectively, in AD (Fig. 7A).

It has been demonstrated that nuclear Cdk5 blocks cell cycle re-entry in an activity-independent way (Zhang and Herrup, 

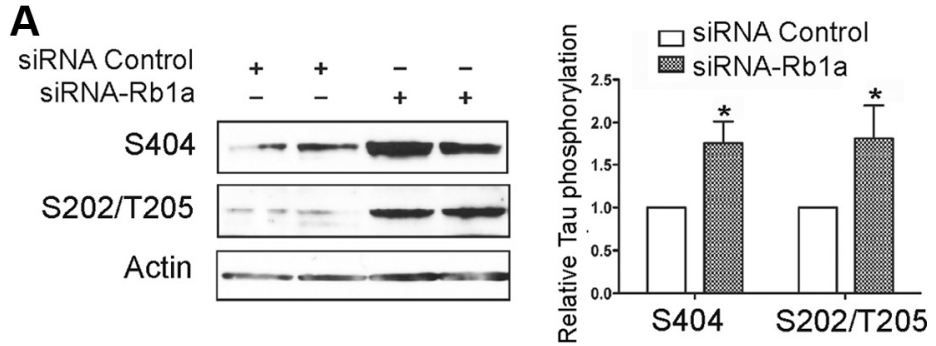

B
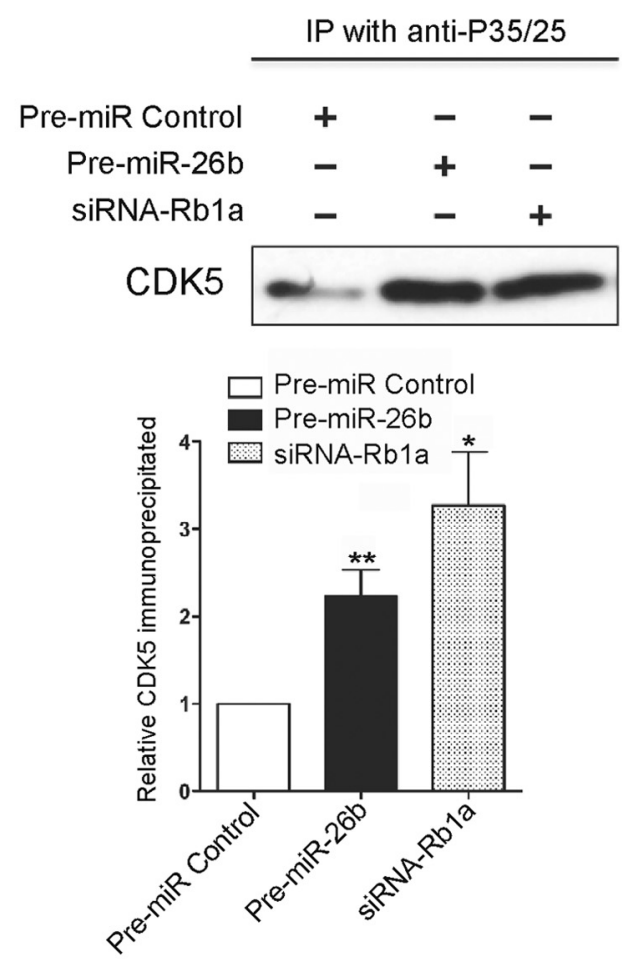

C
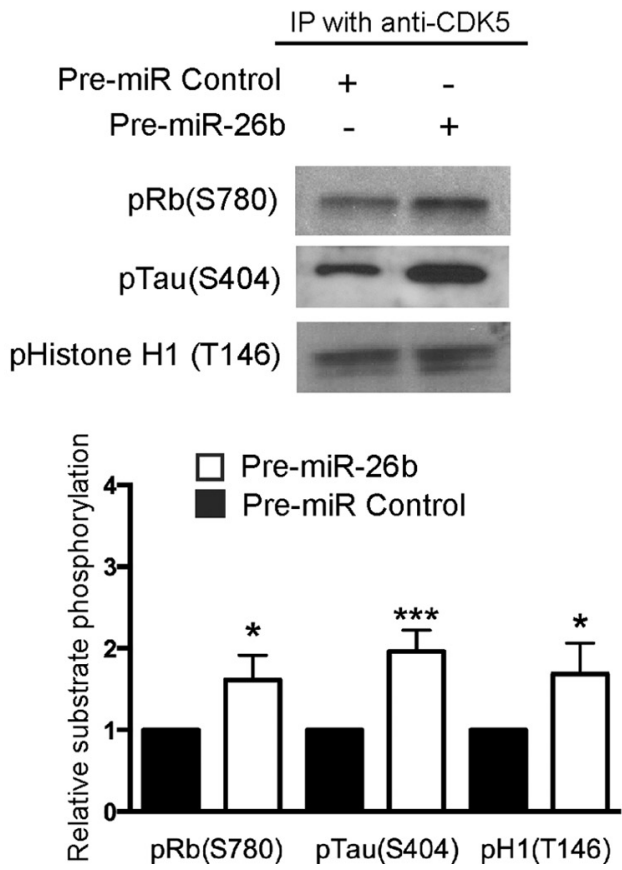

Figure 7. Retinoblastoma downregulation by miR-26b or cognate siRNA leads to an increase in tau-phosphorylation and Cdk5 activity in postmitotic neurons. $\boldsymbol{A}$, Western blot analysis of postmitotic neurons $5 \mathrm{~d}$ after siRNA-Rb1 transfection shows an increase
2008; Zhang et al., 2010). Our data suggest a role for Cdk5 relocalization in the miR26b-induced CCE. For miR-26b/siRNARb-induced tau-hyperphosphorylation, however, Cdk5 kinase activity might be required. To investigate whether miR-26b $\mathrm{OE}$ and $\mathrm{Rb}$ downregulation activate $\mathrm{Cdk} 5$ kinase, we transfected primary cortical neurons with miR-26b or siRNA-Rb and immunoprecipitated the active Cdk5 complex using antibodies to its activator subunit p35/p25. Western blot analysis for the immunoprecipitated complexes revealed a significant increase in active, p35/p25-bound Cdk5 after either miR26b OE or downregulation of Rb by RNAi (Fig. 7B). To directly assess miR-26b effect on the Cdk5 activity we performed in vitro kinase assays on primary cortical neurons. Five days after transfection with either pre-miR-26b or pre-miR control, the neurons were lysed, immunoprecipitated for active Cdk5, and enzymatic activity assays were performed using validated substrate peptides. Of relevance, $\mathrm{Rb} 1$ is a validated substrate of Cdk5 in neuronal cells (Hamdane et al., 2005; Futatsugi et al., 2012); we therefore assessed Cdk5 kinase activity on Rb1, Tau, and also its classical substrate Histone H1. These analyses demonstrated that miR-26b OE increases Cdk5 activity in the phosphorylation of all three tested substrates (Fig. 7C). Therefore, miR-26b OE leads to aberrant CCE and, in parallel, increases tau phosphorylation in neurons, through reduction of $\mathrm{Rb}$ and Cdk5 nuclear export and activation, which appear to be central in the induction of these phenotypes.

\section{Mature neurons exhibit the same effects after treatment with miR-26b and siRNA-Rb}

Since for technical reasons most of our experiments have been performed on primary neurons transfected at 2 DIV, we finally investigated whether miR-26b OE has similar effects on mature synaptically

$\leftarrow$

of tau-phosphorylation at Ser404 and Ser202/Thr205. Actin serves as a loading control (Student's $t$ test, two-tailed, ${ }^{*} p<$ $0.05, n=2)$. $\boldsymbol{B}$, Immunoprecipitation with anti-p35/25 primary antibody followed by Western blot analysis for Cdk5 reveals an accumulation of $\mathrm{Cdk} 5$ associated with p35/p25 in postmitotic neurons transfected with either miR-26b or siRb1 (Student's $t$ test, two-tailed, ${ }^{*} p<0.05$ and ${ }^{* *} p<0.001, n=$ 3). C, Immunoprecipitation for Cdk5 followed by in vitro phosphorylation of its substrate peptides Histone H1, Tau, and Rb1, and Western blot analysis with specified phospho-antibodies indicate increased Cdk5 activity in neurons transfected with pre-miR-26b (Student's $t$ test, two-tailed, ${ }^{* * *} p<0.0005$, $\left.{ }^{*} p<0.01, n=4\right)$. 
A

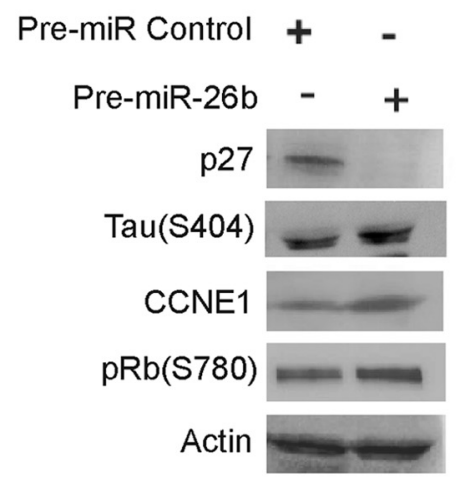

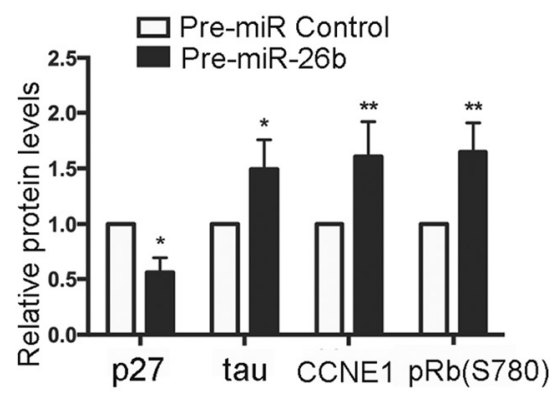

B

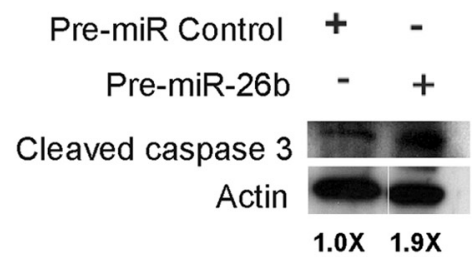

C

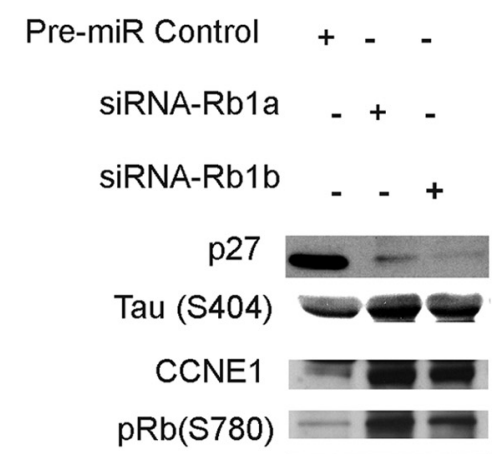

Cleaved caspase 3

Actin

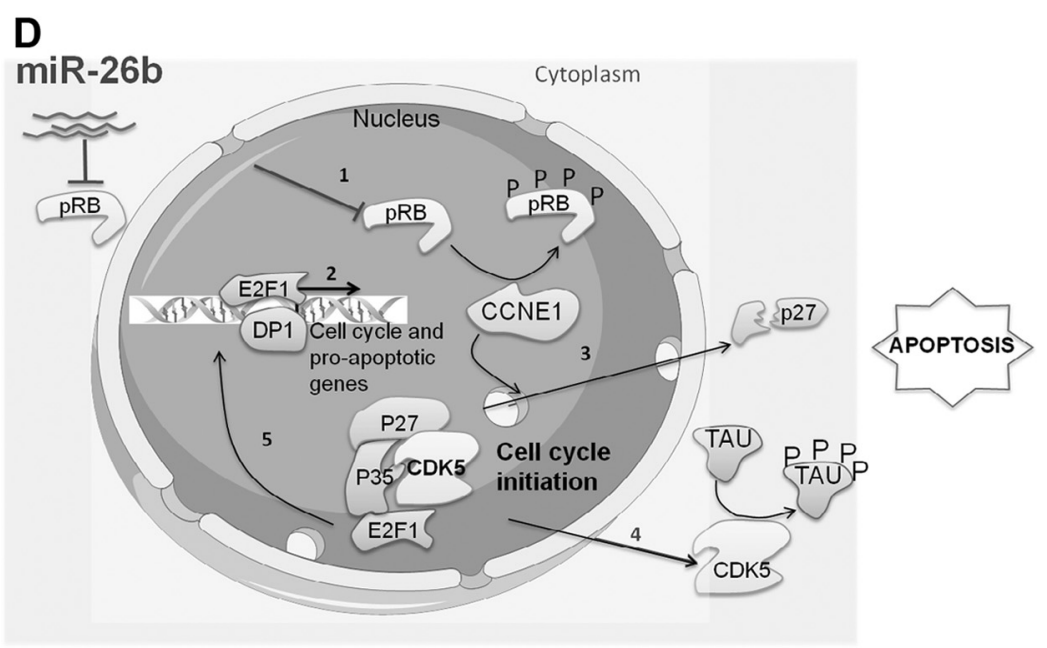

Figure 8. OE of miR-26b or siRNA-mediated knockdown of Rb1 have similar effects in mature cortical neurons transfected at 14 DIV. A, Representative Western blot analysis (left) and quantification of four independent experiments demonstrate that $0 \mathrm{E}$ of miR-26b increases expression of CCNE1 and phosphorylation of Rb1 at Ser780, and tau at Ser404, whereas p27 is downregulated active neurons, as they would represent a better cellular model of neurons in AD. To this end, we cultured primary cortical neurons for 2 weeks before transfecting them via magnetofection with either premiR-26b or pre-miR control and analyzing 3-5 d post-transfection. Similar to young neurons, miR-26b OE downregulated $\mathrm{Rb}$ expression and subsequently led to a significant increase in the levels of CCNE1, phosphorylated Rb, and phosphorylated tau, and to a decrease in p27 levels (Fig. 8A). Furthermore, miR-26b $\mathrm{OE}$ induced apoptosis in these cells, as indicated by increase in cleaved caspase 3 levels $120 \mathrm{~h}$ after transfection (Fig. 8B). Finally, direct knockdown of Rb in mature neurons via siRNA-Rb mimicked principal effects of miR-26b OE. Specifically, it increased the relative expression of CCNE1, phosphorylated Rb, and phosphorylated tau, and decreased the levels of p27 (Fig. 8C). Similar to miR-26b OE, it also led to caspase 3 cleavage in mature neurons (Fig. 8C).

\section{Discussion}

miR-26a/b has been associated with the regulation of cell cycle and apoptosis in cancer cells, acting in different cellular contexts either as a growth-promoting or as a growth-suppressive miRNA (Huse et al., 2009; Kota et al., 2009; Kim et al., 2010; Lu et al., 2011; Zhu et al., 2012a). Our work demonstrates that miR-26b is upregulated in temporal cortex in $\mathrm{AD}$, starting from early prodromal stages, and in postmitotic rodent and human neurons it may induce aberrant CCE, increase tauphosphorylation, and lead to apoptotic cell death.

It is documented in $\mathrm{AD}$ brains that neurons of the hippocampus and cerebral cortex demonstrate appearance of cell cycle markers and partial or full DNA replication. For example a number of cyclins and CDKs, typical for proliferative cells, appear in postmitotic neurons at early stages of AD (Arendt et al., 1998; Smith et al., 1999). Conversely, many cell cycle inhibitors, including

\section{$\leftarrow$}

(two-way ANOVA, ${ }^{*} p<0.05,{ }^{* *} p<0.005, n=4$ ). $\boldsymbol{B}$, Western blot analysis showing increased cleavage of caspase $35 \mathrm{~d}$ post-transfection with pre-miR-26b (Student's $t$ test, twotailed, ${ }^{*} p<0.05, n=2$ ). C, Western blot analysis demonstrating that mature cortical neurons transfected with two siRNAs cognate to Rb1 have increased expression of CCNE1 and phosphorylation of Rb1 at Ser780, and tau at Ser404, whereas p27 is downregulated. $\boldsymbol{D}$, A model of the proposed miR-26binduced effects on neuronal cell cycle initiation, tauphosphorylation, Cdk5 activity, and apoptosis. 
p27 $7^{\text {kip } 1}$, are downregulated in AD (Janicki and Monteiro, 1999). Reports of cell cycle markers preceding other hallmarks of $\mathrm{AD}$ (A $\beta$ plaques and NFTs) suggest aberrant CCE in postmitotic neurons may be a causative factor or have a key role in the pathogenesis of the disease (Lopes et al., 2009; Bonda et al., 2010; Swerdlow, 2012). While many vulnerable neurons in AD enter S-phase of the cell cycle, exhibit DNA replication and sometimes binucleation events, $\mathrm{M}$-phase is not entered (Bonda et al., 2009; Moh et al., 2011; Yurov et al., 2011). It is generally accepted that neurons entering the cell cycle are ultimately destined for death; better understanding of how aberrant CCE in postmitotic neurons contributes to $\mathrm{AD}$ progression and how it relates to other hallmarks of the disease is vital to help decipher the pathogenesis of $\mathrm{AD}$.

Findings presented in this work suggest elevation of miR26b in AD neurons induces cell cycle, directly targets Rb1, and causes activation of Cdk5, leading to tau-phosphorylation followed by apoptosis. Rb1, a key tumor suppressor protein, regulates cell proliferation by controlling progression through the restriction point within the $G_{1}$-phase of the cell cycle. Hypophosphorylated Rb1 binds and inhibits the transcription factor E2F, which is required for transcription of S-phase genes, while phosphorylation by CDKs inhibits Rb1-E2F binding and thereby allows cell cycle progression. In neurons, Rb1 is expressed at high levels, likely contributing to the postmitotic state of these cells. Remarkably, miR-26b regulates $\mathrm{Rb} 1$ directly by binding to Rb1 mRNA and inhibiting its expression and, consequently, indirectly by functional inactivation through its phosphorylation. Similarly, Rb1 downregulation by siRNA also leads to Rb1 phosphorylation (Fig. 6). Rb1 reduction may lead to phosphorylation of the remaining $\mathrm{Rb} 1$ protein by increasing Cdk5 kinase activity (Fig. $7 \mathrm{~B}, \mathrm{C}$ ). Activated transcription of established E2F targets such as cyclin E and Cdk2 can also lead to elevation of Cdk2-cyclin E that phosphorylates $\mathrm{Rb} 1$, and thereby further drive progression into S-phase (Yoshida et al., 2013).

Although, in addition to $\mathrm{Rb} 1$, miR-26b may regulate other transcripts, Rb1 appears as the major target in postmitotic neurons as its downregulation by siRNA recapitulated pleiotropic effects (including CCE and apoptosis) induced by miR26b (Fig. 6). Downregulated Rb1 expression and activity resulted in elevated transcription of E2F target genes, including both S-phase and pro-apoptotic genes, which may provide a direct link between miR-26b-induced CCE and apoptosis. Furthermore, E2F1 silencing abolishes at least some of the key miR-26b-induced effects in neurons (Fig. 5D). Previous studies support the idea of Rb1/E2F pathway coupling CCE and apoptosis, which is often observed in neurons under stress and in neurodegenerative disorders. For example, E2F OE in cortical neurons is sufficient to induce apoptosis (Hou et al., 2000), whereas lack of E2F confers protection from death induced by $\beta$-amyloid (Giovanni et al., 2000). OE of constitutively active $\mathrm{Rb} 1$ protects neurons from death by camptothecin (Park et al., 2000) and after hypoxic insult (Rashidian et al., 2005). Finally, Rb1 conditional knock-out in mice results in a neurodegeneration of adult forebrain neurons, suggesting postmitotic terminally differentiated neurons require Rb1 for continuous cell cycle repression and survival (Andrusiak et al., 2012).

Altered Rb1/E2F expression and activity have been observed in $\mathrm{AD}$. Several studies reported increased phospho-Rb1 immunoreactivity in neurons during the early stages of AD (JordanSciutto et al., 2003; Hoozemans et al., 2005; Thakur et al., 2008).
An analysis of the transcriptome of brains with different levels of AD severity established a $\sim 1300$ gene signature associated with the disease progression. Notably, more than half of the identified genes (656) were putative E2F transcriptional targets (Gómez Ravetti et al., 2010), further implicating E2F-driven transcription in $\mathrm{AD}$ progression.

Clear effects of miR-26b OE in neurons were seen in the strong upregulation of the E2F target CCNE1, and the corresponding downregulation of CCNE1-CDK2 substrate cell cycle inhibitor p2 $7^{\text {kip } 1}$ (Fig. 2). Zhang et al. (2010) identified p27 as a component of nuclear complex blocking neuronal cell cycle. This complex consisting of p27, Cdk5, and p35, binds to E2F1 and prevents its transcriptional activity. P27 is crucial for nuclear retention of this complex; in conditions of p27 deficiency, Cdk5 is not retained in the nucleus and cannot further suppress E2F-driven transcription, thus eliminating cell cycle suppression. Indeed, in miR-26b overexpressing neurons, p27 reduction was accompanied by the corresponding nuclear export of Cdk5 (Fig. 3). Notably, not only cellular localization of Cdk5 changed but also its enzymatic activity significantly increased, as indicated by the amount of Cdk5 coimmunoprecipitated with its activator p25/p35 and the increased phosphorylation of substrates Rb1, tau, and histone H1 (Fig. 7). Importantly, Cdk5 is one of the key tau kinases involved in pathological tau hyperphosphorylation in AD. Indeed, we observed a significant miR-26b-induced increase in tauphosphorylation at several residues that are Cdk5 epitopes, characteristic for both early and late NFTs, respectively.

In cycling neural and non-neural cells, tau-phosphorylation at AD-related epitopes is cell cycle dependent: it is low in interphase and reaches its peak in mitosis (Preuss et al., 1995; Illenberger et al., 1998). In agreement with previous work describing a link between CCE and tau-phosphorylation (Schindowski et al., 2008; Keeney et al., 2012), we show miR-26b elevation leads to both CCE and tauphosphorylation in neurons. A similarity between the pattern of tau-phosphorylation in dividing neural cells and neurons degenerating in $\mathrm{AD}$ suggests aging neurons respond to inappropriate signals by attempts to enter cell cycle and regenerate, and increased phosphorylation of tau may represent a part of this mechanism.

Frequent coincidents between CCE and hyperphosphorylated tau/NFT in the same neurons have been reported. For example, in $\mathrm{AD}$ and other tauopathies, almost all NFTpositive neurons are also positive for PCNA (Busser et al., 1998) or other cell cycle markers (Bonda et al., 2009). In normally aged brain, AD, and several other tauopathies, phosphorylated Rb1 is detected mostly in neurons that exhibit tau pathology and NFTs (Thakur et al., 2008; Stone et al., 2011). Collectively, these data suggest a spatiotemporal, and perhaps also causative link between CCE and tau-phosphorylation, which is most likely mediated through Cdk5: when it is nuclear it blocks the cell cycle, whereas when exported to the cytosol it does not repress the cell cycle and CCE is induced. It also becomes more enzymatically active as a tau kinase, leading to tau hyperphosphorylation. If this is true, stimuli that induce neuronal CCE by removing the Cdk5 nuclear block might also lead to tau hyperphosphorylation. There are studies that support this, e.g., ectopic cell cycle activation by SV40 oncogene in postmitotic neurons in mice display a neurodegenerative phenotype associated by tau pathology and NFT-like profiles (Park et al., 2007). The aberrant CCE accompanied by tau pathology and changes in neuronal cytoskeleton ultimately lead to apoptosis and neurodegeneration. 
Based on our data and previous studies outlined above, we propose the following model of miR-26b function in $\mathrm{AD}$ pathogenesis. miR-26b is upregulated in neurons at early stages of $\mathrm{AD} / \mathrm{MCI}$ by a yet unknown mechanism. miR-26b directly binds and reduces expression of Rb1, which in turn leads to de-repression of E2F1 and activates transcription of both cell cycle and pro-apoptotic gene targets. Significant increase in CCNE1 may lead to CCNE1/Cdk2-dependent phosphorylation and degradation of p2 $7^{\text {kip } 1}$ (Sheaff et al., 1997; Vlach et al., 1997) followed by the remodeling/dissociation of nuclear p27/Cdk5 complex that normally inhibits cell cycle in neurons. Failure of this block leads to further progression into cell cycle and is accompanied by Cdk5 nuclear export and its increased kinase activity (Fig. $8 D$ ). This, in turn, leads to increased phosphorylation of tau and Rb1, thereby further perpetuating cell cycle, inducing expression of pro-apoptotic genes, and altering microtubule dynamics. Collectively, these profound miR-26b-induced alterations in neuronal metabolism ultimately cause death of postmitotic neurons, at least in vitro. Since numerous Rb1/E2F target genes (both drivers of cell cycle drivers and apoptosis) are induced by miR-26b, the precise molecular mechanism remains to be further investigated. Our data suggest miR-26b-induced neuron death, which happens as a consequence of aberrant CCE, induction of pro-apoptotic genes, and tau-hyperphosphorylation, might represent part of the process underlying $\mathrm{AD}$ pathogenesis. They also suggest inhibition of miR-26 as a novel strategy for neuroprotection.

\section{References}

Akashiba H, Matsuki N, Nishiyama N (2006) p27 small interfering RNA induces cell death through elevating cell cycle activity in cultured cortical neurons: a proof-of-concept study. Cell Mol Life Sci 63:2397-2404. CrossRef Medline

Andorfer C, Acker CM, Kress Y, Hof PR, Duff K, Davies P (2005) Cell-cycle reentry and cell death in transgenic mice expressing nonmutant human tau isoforms. J Neurosci 25:5446-5454. CrossRef Medline

Andrusiak MG, Vandenbosch R, Park DS, Slack RS (2012) The retinoblastoma protein is essential for survival of postmitotic neurons. J Neurosci 32:14809-14814. CrossRef Medline

Arendt T, Holzer M, Gärtner U, Brückner MK (1998) Aberrancies in signal transduction and cell cycle related events in Alzheimer's disease. J Neural Transm Suppl 54:147-158. Medline

Bernocco S, Fondelli C, Matteoni S, Magnoni L, Gotta S, Terstappen GC, Raggiaschi R (2008) Sequential detergent fractionation of primary neurons for proteomics studies. Proteomics 8:930-938. CrossRef Medline

Bommer GT, Gerin I, Feng Y, Kaczorowski AJ, Kuick R, Love RE, Zhai Y, Giordano TJ, Qin ZS, Moore BB, MacDougald OA, Cho KR, Fearon ER (2007) p53-mediated activation of miRNA34 candidate tumorsuppressor genes. Curr Biol 17:1298-1307. CrossRef Medline

Bonda DJ, Evans TA, Santocanale C, Llosá JC, Viña J, Bajic V, Castellani RJ, Siedlak SL, Perry G, Smith MA, Lee HG (2009) Evidence for the progression through S-phase in the ectopic cell cycle re-entry of neurons in Alzheimer disease. Aging 1:382-388. Medline

Bonda DJ, Lee HP, Kudo W, Zhu X, Smith MA, Lee HG (2010) Pathological implications of cell cycle re-entry in Alzheimer disease. Expert Rev Mol Med 12:e19. CrossRef Medline

Busser J, Geldmacher DS, Herrup K (1998) Ectopic cell cycle proteins predict the sites of neuronal cell death in Alzheimer's disease brain. J Neurosci 18:2801-2807. Medline

Byrnes KR, Stoica BA, Fricke S, Di Giovanni S, Faden AI (2007) Cell cycle activation contributes to post-mitotic cell death and secondary damage after spinal cord injury. Brain 130: 2977-2992. CrossRef Medline

Cogswell JP, Ward J, Taylor IA, Waters M, Shi Y, Cannon B, Kelnar K, Kemppainen J, Brown D, Chen C, Prinjha RK, Richardson JC, Saunders AM, Roses AD, Richards CA (2008) Identification of miRNA changes in Alzheimer's disease brain and CSF yields putative biomarkers and insights into disease pathways. J Alzheimers Dis 14:27-41. Medline de las Cuevas N, Urcelay E, Hermida OG, Saíz-Diaz RA, Bermejo F, Ayuso MS, Martín-Requero A (2003) Ca2+/calmodulin-dependent modulation of cell cycle elements pRb and p27kip1 involved in the enhanced proliferation of lymphoblasts from patients with Alzheimer dementia. Neurobiol Dis 13:254-263. CrossRef Medline

Dill H, Linder B, Fehr A, Fischer U (2012) Intronic miR-26b controls neuronal differentiation by repressing its host transcript, ctdsp2. Genes Dev 26:25-30. CrossRef Medline

Futatsugi A, Utreras E, Rudrabhatla P, Jaffe H, Pant HC, Kulkarni AB (2012) Cyclin-dependent kinase 5 regulates E2F transcription factor through phosphorylation of $\mathrm{Rb}$ protein in neurons. Cell Cycle 11: $1603-$

1610. CrossRef Medline

Fu AK, Hung KW, Wong HH, Fu WY, Ip NY (2013) Cdk5 phosphorylates a component of the HDAC complex and regulates histone acetylation during neuronal cell death. Neurosignals 21:55-60. CrossRef Medline

Gabriely G, Wurdinger T, Kesari S, Esau CC, Burchard J, Linsley PS, Krichevsky AM (2008) MicroRNA 21 promotes glioma invasion by targeting matrix metalloproteinase regulators. Mol Cell Biol 28:53695380. CrossRef Medline

Galderisi U, Jori FP, Giordano A (2003) Cell cycle regulation and neural differentiation. Oncogene 22:5208-5219. CrossRef Medline

Giovanni A, Keramaris E, Morris EJ, Hou ST, O’Hare M, Dyson N, Robertson GS, Slack RS, Park DS (2000) E2F1 mediates death of B-amyloid-treated cortical neurons in a manner independent of p53 and dependent on Bax and caspase 3. J Biol Chem 275:11553-11560. CrossRef Medline

Gómez Ravetti M, Rosso OA, Berretta R, Moscato P (2010) Uncovering molecular biomarkers that correlate cognitive decline with the changes of hippocampus' gene expression profiles in Alzheimer's disease. PLoS One 5:e10153. CrossRef Medline

Greene LA, Biswas SC, Liu DX (2004) Cell cycle molecules and vertebrate neuron death: E2F at the hub. Cell Death Differ 11:49-60. CrossRef Medline

Hamdane M, Bretteville A, Sambo AV, Schindowski K, Bégard S, Delacourte A, Bertrand P, Buée L (2005) p25/Cdk5-mediated retinoblastoma phosphorylation is an early event in neuronal cell death. J Cell Sci 118: 12911298. CrossRef Medline

Hammond SM (2006) microRNA detection comes of age. Nat Methods 3:12-13. CrossRef Medline

Hébert SS, Horré K, Nicolaï L, Papadopoulou AS, Mandemakers W, Silahtaroglu AN, Kauppinen S, Delacourte A, De Strooper B (2008) Loss of microRNA cluster miR-29a/b-1 in sporadic Alzheimer's disease correlates with increased BACE1/beta-secretase expression. Proc Natl Acad Sci U S A 105:6415-6420. CrossRef Medline

Hébert SS, Horré K, Nicolaï L, Bergmans B, Papadopoulou AS, Delacourte A, De Strooper B (2009) MicroRNA regulation of Alzheimer's amyloid precursor protein expression. Neurobiol Dis 33:422-428. CrossRef Medline

Hermeking H (2009) MiR-34a and p53. Cell Cycle 8:1308. CrossRef Medline

Hoozemans JJ, van Haastert ES, Veerhuis R, Arendt T, Scheper W, Eikelenboom P, Rozemuller AJ (2005) Maximal COX-2 and ppRb expression in neurons occurs during early Braak stages prior to the maximal activation of astrocytes and microglia in Alzheimer's disease. J Neuroinflammation 2:27. CrossRef Medline

Hou ST, Callaghan D, Fournier MC, Hill I, Kang L, Massie B, Morley P, Murray C, Rasquinha I, Slack R, MacManus JP (2000) The transcription factor E2F1 modulates apoptosis of neurons. J Neurochem 75:91-100. Medline

Huse JT, Brennan C, Hambardzumyan D, Wee B, Pena J, Rouhanifard SH, Sohn-Lee C, le Sage C, Agami R, Tuschl T, Holland EC (2009) The PTEN-regulating microRNA miR-26a is amplified in high-grade glioma and facilitates gliomagenesis in vivo. Genes Dev 23:1327-1337. CrossRef Medline

Hwang HW, Mendell JT (2006) MicroRNAs in cell proliferation, cell death, and tumorigenesis. Br J Cancer 94:776-780. CrossRef Medline

Illenberger S, Zheng-Fischhöfer Q, Preuss U, Stamer K, Baumann K, Trinczek B, Biernat J, Godemann R, Mandelkow EM, Mandelkow E (1998) The endogenous and cell cycle-dependent phosphorylation of tau protein in living cells: implications for Alzheimer's disease. Mol Biol Cell 9:14951512. CrossRef Medline

Janicki SM, Monteiro MJ (1999) Presenilin overexpression arrests cells in 
the G1 phase of the cell cycle. Arrest potentiated by the Alzheimer's disease PS2(N141I)mutant. Am J Pathol 155:135-144. CrossRef Medline

Jaworski T, Dewachter I, Lechat B, Croes S, Termont A, Demedts D, Borghgraef P, Devijver H, Filipkowski RK, Kaczmarek L, Kügler S, Van Leuven F (2009) AAV-tau mediates pyramidal neurodegeneration by cell-cycle re-entry without neurofibrillary tangle formation in wild-type mice. PLoS One 4:e7280. CrossRef Medline

Jordan-Sciutto KL, Malaiyandi LM, Bowser R (2002) Altered distribution of cell cycle transcriptional regulators during Alzheimer disease. J Neuropathol Exp Neurol 61:358-367. Medline

Jordan-Sciutto KL, Dorsey R, Chalovich EM, Hammond RR, Achim CL (2003) Expression patterns of retinoblastoma protein in Parkinson disease. J Neuropathol Exp Neurol 62:68-74. Medline

Keeney JT, Swomley AM, Harris JL, Fiorini A, Mitov MI, Perluigi M, Sultana $\mathrm{R}$, Butterfield DA (2012) Cell cycle proteins in brain in mild cognitive impairment: insights into progression to Alzheimer disease. Neurotox Res 22:220-230. CrossRef Medline

Kim H, Huang W, Jiang X, Pennicooke B, Park PJ, Johnson MD (2010) Integrative genome analysis reveals an oncomir/oncogene cluster regulating glioblastoma survivorship. Proc Natl Acad Sci U S A 107: 2183-2188. CrossRef Medline

Kota J, Chivukula RR, O’Donnell KA, Wentzel EA, Montgomery CL, Hwang HW, Chang TC, Vivekanandan P, Torbenson M, Clark KR, Mendell JR, Mendell JT (2009) Therapeutic microRNA delivery suppresses tumorigenesis in a murine liver cancer model. Cell 137:1005-1017. CrossRef Medline

Krichevsky AM, Kosik KS (2001) Neuronal RNA granules: a link between RNA localization and stimulation-dependent translation. Neuron 32: 683-696. CrossRef Medline

Lau P, de Strooper B (2010) Dysregulated microRNAs in neurodegenerative disorders. Semin Cell Dev Biol 21:768-773. CrossRef Medline

Lee MS, Tsai LH (2003) Cdk5: one of the links between senile plaques and neurofibrillary tangles? J Alzheimers Dis 5:127-137. Medline

Liu N, Landreh M, Cao K, Abe M, Hendriks GJ, Kennerdell JR, Zhu Y, Wang LS, Bonini NM (2012) The microRNA miR-34 modulates ageing and neurodegeneration in Drosophila. Nature 482:519-523. CrossRef Medline

Lopes JP, Blurton-Jones M, Yamasaki TR, Agostinho P, LaFerla FM (2009) Activation of cell cycle proteins in transgenic mice in response to neuronal loss but not amyloid-beta and tau pathology. J Alzheimers Dis 16:541549. Medline

Lu J, He ML, Wang L, Chen Y, Liu X, Dong Q, Chen YC, Peng Y, Yao KT, Kung HF, Li XP (2011) MiR-26a inhibits cell growth and tumorigenesis of nasopharyngeal carcinoma through repression of EZH2. Cancer Res 71:225-233. CrossRef Medline

Manning AL, Dyson NJ (2011) pRB, a tumor suppressor with a stabilizing presence. Trends Cell Biol 21:433-441. CrossRef Medline

Mazanetz MP, Fischer PM (2007) Untangling tau hyperphosphorylation in drug design for neurodegenerative diseases. Nat Rev Drug Discov 6:464479. CrossRef Medline

McShea A, Lee HG, Petersen RB, Casadesus G, Vincent I, Linford NJ, Funk JO, Shapiro RA, Smith MA (2007) Neuronal cell cycle re-entry mediates Alzheimer disease-type changes. Biochim Biophys Acta 1772: 467-472. CrossRef Medline

Moh C, Kubiak JZ, Bajic VP, Zhu X, Smith MA, Lee HG (2011) Cell cycle deregulation in the neurons of Alzheimer's disease. Results Probl Cell Differ 53:565-576. CrossRef Medline

Muñoz U, de Las Cuevas N, Bartolomé F, Hermida OG, Bermejo F, MartínRequero A (2005) The cyclopentenone 15-deoxy-delta(12,14)prostaglandin J2 inhibits G1/S transition and retinoblastoma protein phosphorylation in immortalized lymphocytes from Alzheimer's disease patients. Exp Neurol 195:508-517. CrossRef Medline

Nagy Z, Esiri MM, Cato AM, Smith AD (1997) Cell cycle markers in the hippocampus in Alzheimer's disease. Acta Neuropathol 94:6-15. CrossRef Medline

Neve RL, McPhie DL (2006) The cell cycle as a therapeutic target for Alzheimer's disease. Pharmacol Ther 111:99-113. CrossRef Medline

Park DS, Morris EJ, Bremner R, Keramaris E, Padmanabhan J, Rosenbaum M, Shelanski ML, Geller HM, Greene LA (2000) Involvement of retinoblastoma family members and E2F/DP complexes in the death of neurons evoked by DNA damage. J Neurosci 20:3104-3114. Medline

Park KH, Hallows JL, Chakrabarty P, Davies P, Vincent I (2007) Condi- tional neuronal simian virus $40 \mathrm{~T}$ antigen expression induces Alzheimerlike tau and amyloid pathology in mice. J Neurosci 27:2969-2978. CrossRef Medline

Preuss U, Döring F, Illenberger S, Mandelkow EM (1995) Cell cycledependent phosphorylation and microtubule binding of tau protein stably transfected into Chinese hamster ovary cells. Mol Biol Cell 6:13971410. Medline

Provost P (2010) Interpretation and applicability of microRNA data to the context of Alzheimer's and age-related diseases. Aging 2:166-169. Medline

Ranganathan S, Scudiere S, Bowser R (2001) Hyperphosphorylation of the retinoblastoma gene product and altered subcellular distribution of E2F-1 during Alzheimer's disease and amyotrophic lateral sclerosis. J Alzheimers Dis 3:377-385. Medline

Rashidian J, Iyirhiaro G, Aleyasin H, Rios M, Vincent I, Callaghan S, Bland RJ, Slack RS, During MJ, Park DS (2005) Multiple cyclin-dependent kinases signals are critical mediators of ischemia/hypoxic neuronal death in vitro and in vivo. Proc Natl Acad Sci U S A 102:14080-14085. CrossRef Medline

Rogakou EP, Pilch DR, Orr AH, Ivanova VS, Bonner WM (1998) DNA double-stranded breaks induce histone $\mathrm{H} 2 \mathrm{AX}$ phosphorylation on serine 139. J Biol Chem 273:5858-5868. CrossRef Medline

Satoh J (2012) Molecular network of microRNA targets in Alzheimer's disease brains. Exp Neurol 235:436-446. CrossRef Medline

Schindowski K, Belarbi K, Bretteville A, Ando K, Buée L (2008) Neurogenesis and cell cycle-reactivated neuronal death during pathogenic tau aggregation. Genes Brain Behav 7 [Suppl]1:92-100. CrossRef Medline

Schwartz EI, Smilenov LB, Price MA, Osredkar T, Baker RA, Ghosh S, Shi FD, Vollmer TL, Lencinas A, Stearns DM, Gorospe M, Kruman II (2007) Cell cycle activation in postmitotic neurons is essential for DNA repair. Cell Cycle 6:318-329. CrossRef Medline

Sellers WR, Rodgers JW, Kaelin WG Jr (1995) A potent transrepression domain in the retinoblastoma protein induces a cell cycle arrest when bound to E2F sites. Proc Natl Acad Sci U S A 92: 11544-11548. CrossRef Medline

Seward ME, Swanson E, Norambuena A, Reimann A, Cochran JN, Li R, Roberson ED, Bloom GS (2013) Amyloid-beta signals through tau to drive ectopic neuronal cell cycle re-entry in Alzheimer's Disease. J Cell Sci 126:1278-1286. CrossRef Medline

Sheaff RJ, Groudine M, Gordon M, Roberts JM, Clurman BE (1997) Cyclin E-CDK2 is a regulator of p27Kip1. Genes Dev 11:1464-1478. CrossRef Medline

Smith DS, Leone G, DeGregori J, Ahmed MN, Qumsiyeh MB, Nevins JR (2000) Induction of DNA replication in adult rat neurons by deregulation of the retinoblastoma/E2F G1 cell cycle pathway. Cell Growth Differ 11:625-633. Medline

Smith MZ, Nagy Z, Esiri MM (1999) Cell cycle-related protein expression in vascular dementia and Alzheimer's disease. Neurosci Lett 271: 45-48. CrossRef Medline

Smith PY, Delay C, Girard J, Papon MA, Planel E, Sergeant N, Buée L, Hébert SS (2011) MicroRNA-132 loss is associated with tau exon 10 inclusion in progressive supranuclear palsy. Hum Mol Genet 20: 4016-4024. CrossRef Medline

Stone JG, Siedlak SL, Tabaton M, Hirano A, Castellani RJ, Santocanale C, Perry G, Smith MA, Zhu X, Lee HG (2011) The cell cycle regulator phosphorylated retinoblastoma protein is associated with tau pathology in several tauopathies. J Neuropathol Exp Neurol 70:578-587. CrossRef Medline

Swerdlow RH (2012) Alzheimer's disease pathologic cascades: who comes first, what drives what. Neurotox Res 22:182-194. CrossRef Medline

Thakur A, Siedlak SL, James SL, Bonda DJ, Rao A, Webber KM, Camins A, Pallàs M, Casadesus G, Lee HG, Bowser R, Raina AK, Perry G, Smith MA, Zhu X (2008) Retinoblastoma protein phosphorylation at multiple sites is associated with neurofibrillary pathology in Alzheimer disease. Int J Clin Exp Pathol 1:134-146. Medline

Vilardo E, Barbato C, Ciotti M, Cogoni C, Ruberti F (2010) MicroRNA-101 regulates amyloid precursor protein expression in hippocampal neurons. J Biol Chem 285:18344-18351. CrossRef Medline

Vincent I, Jicha G, Rosado M, Dickson DW (1997) Aberrant expression of mitotic cdc2/cyclin B1 kinase in degenerating neurons of Alzheimer's disease brain. J Neurosci 17:3588-3598. Medline

Vlach J, Hennecke S, Amati B (1997) Phosphorylation-dependent deg- 
radation of the cyclin-dependent kinase inhibitor p27. EMBO J 16: 5334-5344. CrossRef Medline

Wang WX, Huang Q, Hu Y, Stromberg AJ, Nelson PT (2011) Patterns of microRNA expression in normal and early Alzheimer's disease human temporal cortex: white matter versus gray matter. Acta Neuropathol 121: 193-205. CrossRef Medline

Wong HK, Veremeyko T, Patel N, Lemere CA, Walsh DM, Esau C, Vanderburg C, Krichevsky AM (2013) De-repression of FOXO3a death axis by microRNA-132 and -212 causes neuronal apoptosis in Alzheimer's disease. Hum Mol Genet 22:3077-3092. CrossRef Medline

Yang Y, Geldmacher DS, Herrup K (2001) DNA replication precedes neuronal cell death in Alzheimer's disease. J Neurosci 21:2661-2668. Medline

Ye W, Blain SW (2010) S phase entry causes homocysteine-induced death while ataxia telangiectasia and $\operatorname{Rad} 3$ related protein functions antiapoptotically to protect neurons. Brain 133: 2295-2312. CrossRef Medline

Yoshida A, Yoneda-Kato N, Kato JY (2013) CSN5 specifically interacts with CDK2 and controls senescence in a cytoplasmic cyclin E-mediated manner. Sci Rep 3:1054. Medline

Yurov YB, Vorsanova SG, Iourov IY (2011) The DNA replication stress hypothesis of Alzheimer's disease. ScientificWorldJournal 11:26022612. CrossRef Medline
Zhang J, Li H, Herrup K (2010) Cdk5 nuclear localization is p27-dependent in nerve cells: implications for cell cycle suppression and caspase- 3 activation. J Biol Chem 285:14052-14061. CrossRef Medline

Zhang J, Herrup K (2008) Cdk5 and the non-catalytic arrest of the neuronal cell cycle. Cell Cycle 7:3487-3490. CrossRef Medline

Zhang J, Cicero SA, Wang L, Romito-Digiacomo RR, Yang Y, Herrup K (2008) Nuclear localization of Cdk5 is a key determinant in the postmitotic state of neurons. Proc Natl Acad Sci U S A 105:8772-8777. CrossRef Medline

Zhu Y, Lu Y, Zhang Q, Liu JJ, Li TJ, Yang JR, Zeng C, Zhuang SM (2012a) MicroRNA-26a/b and their host genes cooperate to inhibit the $\mathrm{G}_{1} / \mathrm{S}$ transition by activating the pRb protein. Nucleic Acids Res 40:4615-4625. CrossRef Medline

Zhu HC, Wang LM, Wang M, Song B, Tan S, Teng JF, Duan DX (2012b) MicroRNA-195 downregulates Alzheimer's disease amyloid-beta production by targeting BACE1. Brain Res Bull 88:596-601. CrossRef Medline

Zovoilis A, Agbemenyah HY, Agis-Balboa RC, Stilling RM, Edbauer D, Rao P, Farinelli L, Delalle I, Schmitt A, Falkai P, Bahari-Javan S, Burkhardt S, Sananbenesi F, Fischer A (2011) microRNA-34c is a novel target to treat dementias. EMBO J 30:4299-4308. CrossRef Medline 